HOMI KHARAS

World Bank

B R I A N PINTO

World Bank

SERGEI ULATOV

World Bank

\title{
An Analysis of Russia's 1998 Meltdown: Fundamentals and Market Signals
}

On August 17, 1998, a little more than a month after an international package of emergency financing and economic reforms was announced, Russia was forced to devalue the ruble. ${ }^{1}$ Russia also declared its intention to restructure all official domestic currency debt obligations falling due to the end of 1999 and imposed a ninety-day moratorium on the repayment of private external debt, to aid its commercial banks. The moratorium also applied to these banks' obligations from short positions on currency forward contracts, as well as margin calls on repurchase operations (repos) with foreign banks. Less than three weeks later, on September 2, the Central Bank of Russia (CBR) floated the ruble. By September 9 the exchange rate had reached 21 rubles to the dollar, more than three times the 6.29 rubles to the dollar that had prevailed on August 14.

The authors thank Pierre-Richard Agenor, Joshua Aizenman, Robert J. Anderson, Gerard Belanger, Robert Cumby, Robert Flood, Victor Gabor, Eric Jayaweera, Thomas Laursen, Pradeep Mitra, and Marcelo Selowsky for helpful comments, and Peter Boone and Brunswick UBS Warburg in Moscow for sharing their securities data sets. The authors are also grateful to the discussants and the other participants on the Brookings Panel for their comments. The findings, interpretations, and conclusions expressed in this paper are entirely those of the authors, and should not be attributed in any manner to the World Bank, its affiliated organizations, or the members of its Board of Directors or the countries they represent.

1. The devaluation was achieved by widening the trading band of the ruble to 6.0 to 9.5 rubles to the dollar; the central bank rate had been 6.29 to the dollar on August 14, 1998 . The move has therefore been called a de facto devaluation. 
The free fall of the ruble and the disruption in the government's access to market borrowing were costly, with an output decline, bank failures, and a spike in inflation. Russia ended 1998 with an output contraction of 4.9 percent for the year, compared with initial expectations of slight growth. Inflation for the year as a whole was 84 percent, compared with an original target of 8 percent. On the political front, the reformist government of Sergei Kirienko was dismissed in the wake of the devaluation, leading to fears of policy reversals and a return to hyperinflation.

In an effort to avoid these economic and political costs and achieve a soft landing for the economy, a $\$ 22.6$ billion international financing package to support fiscal and structural reforms had been announced on July 13. The package was designed to maintain the preannounced exchange rate band while buying time to implement what were recognized as difficult and time-consuming reforms, through an injection of liquidity into reserves and a swap out of short-term ruble treasury bills (called GKOs) into long-term Eurobonds. ${ }^{2}$ The objective of the swap was to address the rollover risk from the maturing of large volumes of GKOs each week, totaling $\$ 32.7$ billion over the last seven months of 1998. It was envisaged that the announcement of the package would stabilize the market, reduce real interest rates to levels the government could afford, and take the pressure off the exchange rate. Indeed, GKO yields halved the next day but remained in excess of 50 percent, far above the 8 percent inflation target. By July 24, upon completion of the GKO-Eurobond swap, GKO yields had jumped to 66 percent, and they kept rising until the August 17 devaluation.

Two factors apparently underlay the decision not to abandon the exchange rate band. First, for the Russians, the attainment of single-digit inflation in early 1998 (twelve-month inflation dipped below 10 percent from February until July) represented a major policy achievement, one that they would abandon only with great reluctance. Second, the recent East Asian experience with devaluation had been bad, especially in Indonesia. During the crises in some of those countries in 1997-98, attempts to float had precipitated free falls of the currency, damaging exposed banks and corporations as well as reducing output and raising inflation, and imposing

2. The CBR had announced on November 10, 1997, that the exchange rate would be targeted at a central rate of 6.2 rubles to the dollar, with a fluctuation band of \pm 15 percent, for three years beginning January 1, 1998. 
large welfare costs. As a result, there was strong motivation in the Russian case to try and maintain market sentiment and access until fiscal and structural reforms could deliver results. This soft landing scenario implicitly underpinned the international package, which also recognized that Russia's fiscal and structural problems admitted no quick fixes.

The package did not achieve its objectives. Total foreign exchange resources, including reserves and new external borrowings, used to defend the ruble between the first speculative attack in late October 1997 and the September 2, 1998, decision to float the currency amounted to $\$ 30$ billion, about one-sixth of postcrisis GDP. ${ }^{3}$ Russian-era foreign currency debt of the federal government increased by $\$ 20.5$ billion over the same period. ${ }^{4}$ Of this, no less than $\$ 16$ billion, or 8 percent of postcrisis GDP, was accumulated over the ten weeks preceding the meltdown, through a combination of official and private new money and the GKO-Eurobond exchange. The international financial institutions-the International Monetary Fund (IMF) and the World Bank-eventually disbursed only one-fourth of the total funds announced as part of the July package. Table 1 presents a breakdown of funds received by Russia between June 1 and August 17, 1998.

Interestingly, \$16 billion is also approximately the value of the losses that external creditors have now been forced to take, which suggests that Russia had already reached its overall exposure limit for external debt by the end of May 1998. At the end of 1998, Russia obtained a preliminary flow rescheduling (later finalized) of most of its debt service obligations falling due during 1999 and 2000 on the Paris Club component of its Soviet-era debt (debt incurred by the Soviet Union before January 1, 1992, which Russia inherited), and in August 2000 an agreement was reached on

3. Approximately $\$ 27$ billion was used to defend the ruble between October 1, 1997, and the devaluation of August 17, 1998, followed by another $\$ 2.8$ billion before the currency was floated.

4. Russian-era foreign currency debt refers to all debt issued from January 1, 1992, onward and includes Eurobonds, MinFin bonds VI and VII, loans from other commercial sources, and loans from the World Bank, the International Monetary Fund, the European Bank for Reconstruction and Development, and bilateral sources. (Dollar-denominated MinFin bonds, which totaled $\$ 11$ billion, were issued after the collapse of the Soviet Union to compensate holders of foreign currency accounts with the state-owned Vneshekonombank. Five tranches were issued in 1993, classified as part of Soviet-era debt, and an additional two tranches-VI and VII-were issued in 1996, classified as part of the debt of the Russian Federation.) 
Table 1. International Financing in the Weeks Preceding the Devaluation

\begin{tabular}{llc}
\hline Date & \multicolumn{1}{c}{ Method of finance } & Value (billions of dollars) \\
\hline June 4, 1998 & Eurobond & 1.25 \\
June 18, 1998 & Eurobond & 2.50 \\
June 25, 1998 & IMF tranche & 0.67 \\
July 20, 1998 & IMF tranche & 4.80 \\
July 24, 1998 & Eurobond & $6.44^{\mathrm{a}}$ \\
July 1998 & Japanese cofinancing with World Bank loans & 0.40 \\
August 6, 1998 & First tranche of World Bank SAL3 & 0.30 \\
& Total & 16.36 \\
\hline
\end{tabular}

Sources: IMF, Russian Ministry of Finance, and World Bank data.

a. $\$ 5.9$ billion related to the GKO-Eurobond swap plus $\$ 0.5$ billion in new money.

the London Club component of that debt. This agreement included a writedown of a third of the face value of $\$ 31.8$ billion; the total reduction in present value terms has been estimated at over 50 percent. ${ }^{5}$ Although these debt restructurings appear to offset the incremental debt identified above, other costs typically incurred in such circumstances-such as loss of reputation and loss of trade financing and other banking services—should not be ignored. However, despite widespread expectations that the recession and crisis would deepen, the macroeconomic situation reversed in 1999. Aided by the devaluation, domestic industry rebounded strongly, output actually increased by 5.4 percent in 1999, and inflation was brought back below 40 percent and remained on a downward trend. ${ }^{6}$

Two broad analytical approaches can be used to try to explain why the July 1998 package did not work and why the August speculative attack on the ruble succeeded. The first approach is based on so-called firstgeneration crisis models, which emphasize fiscal fundamentals, credit rationing, and inconsistencies between fiscal and exchange rate policies. The typical first-generation crisis arises from a growing fiscal deficit

5. Paris Club debt is a subset of Soviet-era debt owed to official bilateral creditors; London Club debt is that owed to private sector institutions. The latter had three components: Prins ( $\$ 22.2$ billion), IANs ( $\$ 6.8$ billion), and past-due interest on the first two components ( $\$ 2.8$ billion). The write-off of $\$ 10.6$ billion applied to the Prins and IANs. (Prins and IANs are debt payable by Vneshekonombank that was restructured from commercial bank loans in December 1997.) The conversion of London Club liabilities into Russian Federation Eurobonds was completed by the end of August 2000. For details see Deutsche Bank Global Markets Research, "Russia London Club Restructuring," July 20, 2000; and Fitch IBCA, Duff \& Phelps, "Sovereign Report: Russia," August 31, 2000.

6. Ahrend (1999) provides an analysis of the spectacular effects of the real devaluation. See also IMF (2000a). 
financed by domestic credit in the face of a fixed exchange rate and finite reserves, leading eventually to a speculative attack when credit limits imposed by lenders are reached. In contrast, the newly popular secondgeneration models emphasize the presence of multiple equilibria, where changes in market sentiment or confidence can trigger a sudden capital outflow and precipitate a crisis even when the fundamentals are sound. ${ }^{7}$

In the real world, fundamentals and confidence are intertwined. The key fundamentals in the case of Russia centered around fiscal deficits and the dynamics of the public debt, and the prospects for sustained economic growth. The attempt to persuade the market that an immediate exchange rate correction was not needed, so that real interest rates would come down while the fundamentals were being fixed, resonates with second-generation models, which emphasize the shifting nature of market confidence and expectations. These models typically feature at least two stable equilibria, commonly referred to as a good state and a bad state. A financial crisis results when shifting creditor expectations trigger a move from the good to the bad state. In these models, illiquidity and expectations are key. Second-generation models are most useful in explaining why financial crises can spread quickly across many countries, and they suggest that crises and devaluations need not occur if timely measures are taken to boost liquidity.

The package for Russia was the first to include a major, preemptive infusion of external liquidity before the crisis from both official and private lenders. Another distinctive feature was the attempt to reduce rollover risk and lengthen debt maturity through the GKO-Eurobond swap. Accompanying fiscal and structural reforms were designed to strengthen the fundamentals but left the exchange rate band untouched. The package therefore was built upon two key assumptions. The first was that securing visible improvements in Russia's fiscal and structural fundamentals would require sustained implementation of the announced reforms. The second was that, in the meantime, local and international capital markets would continue to provide sufficient capital to maintain the fixed nominal exchange rate band if confidence could be boosted.

7. First-generation models are typified by those of Krugman (1979) and Flood and Garber (1984); Furman and Stiglitz (1998) and Eichengreen, Rose, and Wyplosz (1996) are examples of second-generation models. 
We argue that, by mid-May 1998, Russia's economic situation was characterized by rapidly growing public debt, weak growth prospects, the need for time-consuming reforms to correct fiscal and structural fundamentals, and market signals of exceptionally high levels of default and devaluation risk, in the form of high marginal interest rates on public debt. ${ }^{8}$ On the basis of this combination of fundamentals and market signals, we try to show that the sequence of events in the Russian crisis is best explained by an inconsistency between the fiscal imbalances and the fixed exchange rate band, generating dynamics along the lines of the firstgeneration models. From this perspective, the Russian crisis was in the making at least since 1996, and by May 1998 Russia was exhibiting classic signs of a fundamentals-based speculative attack. Therefore the probability of achieving a soft landing based on maintaining the fixed exchange rate band, as sought by the July 1998 package, was low. We also argue that the liquidity injection and GKO-Eurobond swap, which added a considerable amount of new foreign debt, may not have bought time and may even have advanced the speculative attack by adding senior debt to the existing debt stock. This may happen if markets perceive that the necessary fiscal and structural measures in the program may be too little and too late to compensate for the increased debt burden induced by the program itself.

The next section presents a chronology of events. We then analyze the fundamental problem with financing the fiscal deficit and show that markets started to respond decisively to greater devaluation and default risk by May 15, 1998, over three months before the crisis finally broke. Next we discuss the interaction among declining liquidity, rising bank vulnerability, and the GKO-Eurobond swap as a decisive factor determining the timing of the speculative attack. The last section extracts lessons.

\section{Timeline and Background}

The appendix presents a chronology of events between October 1997, when the first spillover from the Asian crisis occurred, and early Novem-

8. Note that this last observation is contrary to those of studies of second-generation crises, which highlight the failure of interest rate differentials preceding the crisis to compensate for the anticipated devaluation. 
ber 1998, when the Russian deputy prime minister in charge of the economy admitted that Russia would not be able to meet its sovereign debt payments. The discussion below centers around the three episodes of instability that Russia endured prior to the meltdown: in October 1997, at the start of the crisis; in January 1998, when investor concerns over Russian fundamentals intensified; and in May 1998, when the final episode began.

Inflation and interest rates had come down over the first ten months of 1997, and Russia was about to register its first year of positive growth since the start of transition. Portfolio investors had thronged to the markets for Russian equities, GKOs, and OFZs (ruble treasury notes), driving up the reserves of the CBR to record levels: some $\$ 25$ billion by July. But the fiscal accounts were marked by a chronic shortfall in cash tax collection, which prompted the IMF mission to leave at the end of October without recommending completion of its review, thereby holding up disbursements of IMF loans. ${ }^{9}$ This coincided with the first bout of instability as Korean and Brazilian investors, facing liquidity pressures at home, began exiting the GKO market. ${ }^{10}$ The CBR attempted to calm the markets by announcing that, starting in January 1998, it would target a central exchange rate parity for the ruble of 6.2 to the dollar within a fluctuation band of \pm 15 percent; the exchange rate at the time was 5.9 rubles to the dollar. The CBR eventually got the situation under control by raising interest rates, although it lost a substantial amount of reserves in the process.

The crisis prompted the government to formulate a Fiscal Action Plan with the IMF in November 1997, to address not only the tax collection problem but expenditure control as well. An end-of-year inflation target of 8 percent and a flat real exchange rate were announced for 1998 as part of the budget package for 1998, which the Duma passed in its first reading on December 5, 1997.

9. As argued in Pinto, Drebentsov, and Morozov (2000a and b), this tax shortfall was symptomatic of much deeper economic problems in Russia, and not just a matter of summoning the political will to crack down on tax delinquents. It reflected large implicit subsidies transferred by the energy monopolies, the biggest tax delinquents, to manufacturing firms as part of a system of soft budget constraints.

10. This and other details of events have been confirmed in informal conversations between Brian Pinto and investment bank analysts based in Moscow. 
By the end of January 1998, however, investor concerns about the fiscal situation and "policy drift" in relation to structural reforms had intensified, leading to a second speculative attack. ${ }^{11}$ A credibility gap was developing, which the East Asian crisis accentuated: if those economies, with their established private sectors and track record of prudent macroeconomic management, were in disarray, why not also Russia? ${ }^{12}$ In an attempt to counter this sentiment, President Boris Yeltsin made a series of tough pronouncements on protecting minority shareholder rights, renouncing tax offsets, and providing a good climate for foreign direct investment, including tax reform and passage of the 1998 budget; he used his February 17 State of the Nation address to reinforce these positive signals. ${ }^{13}$

In early March, the Duma passed the 1998 budget in its final reading with the Ministry of Finance's tough expenditure controls intact. However, this was soon followed by several weeks of political turmoil, with Prime Minister Viktor Chernomyrdin dismissed on March 23, 1998, and Kirienko finally confirmed in a political cliffhanger on the third vote on April 24.

The third and final bout of instability began in mid-May, coinciding with the intensification of the Indonesian political and financial crisis. With interest rates soaring, oil prices plunging, and growth prospects vanishing, Russia's public debt dynamics were increasingly becoming a matter of concern, and by June the government was talking openly of combating the "financial crisis." It began tapping the Eurobond market, seeking to move away from what was regarded as "expensive, short-term ruble debt" (that is, GKOs) to "cheaper, longer term dollar debt" (Eurobonds), and managed to raise a total of $\$ 3.8$ billion from Eurobonds issued on June 4 and 18. It also skipped GKO auctions, in effect using the dollar proceeds of the Eurobonds to redeem maturing GKOs. Eventually, a macroeconomic program was negotiated for 1998 that kept unchanged the inflation and real exchange rate targets ( 8 percent and flat, respectively) that had been negotiated the previous year. The IMF released a $\$ 670$ million tranche of its Extended Fund Facility arrangement with Russia on June 25.

11. In private conversations, analysts at local investment banks called this the "Davos effect"-Russia's key policymakers were all in Davos, Switzerland, at the time for the annual World Economic Forum.

12. Slay (1999) calls this a global repricing of risk.

13. Tax offsets are deals between the government and large tax debtors, in particular, to settle mutual debts arising from government spending arrears and tax arrears. 
Around the same time, the Kirienko government presented its anti-crisis Economic Stabilization and Finance Program. ${ }^{14}$ An accompanying report traced the crisis to 1995, when money financing of the deficit had ceased. But, the report noted, this had not been accompanied by better tax compliance and spending restraint. Instead, the government had relied on issuing debt while permitting a proliferation of tax offsets. The crisis was attributed to three factors: fiscal deficits and mounting interest payments; an unfavorable public debt structure, with predominance of short-term, high-yielding GKOs in new borrowings; and contagion effects from the Asian crisis combined with a decline in oil and gas prices. To restore investor confidence and policy credibility, two crucial actions were singled out. The government would aim for a significant primary fiscal surplus for 1999, thereby minimizing borrowing and lowering interest rates; it would also resolve the nonpayments and barter crisis (described below), thus creating the conditions for output recovery, income growth, and expansion of the tax base.

On June 23, negotiations began on an IMF-World Bank-Government of Japan package to support the ruble and restore confidence. A $\$ 22.6$ billion package was announced on July 13, on the same day that the Russian government released the details of a plan designed to swap GKOs into long-term Eurobonds. Box 1 lists the key features of the package. As noted in the introduction, GKO yields halved the next day but remained in excess of 50 percent. The IMF's board of directors approved the package on July 20. Four days later, however, upon completion of a limited GKOEurobond swap, GKO yields were back to the levels of mid-June.

Russian banks came under increasing liquidity pressure in August, when rollovers on syndicated loans from Western banks peaked at about $\$ 500$ million. Key Russian banks such as SBS-Agro were also exposed to changes in the price of domestic and external Russian government debt. They had entered into repurchase arrangements with foreign banks, collateralized with their holdings of Russian government dollar-denominated paper. The GKO-Eurobond swap completed on July 24 greatly increased the amount of Russian sovereign dollar-denominated debt, depressing its price and triggering calls for more collateral. As cash-strapped Russian banks offloaded their holdings of GKOs and other domestic government

14. The core measures were outlined in two documents, "Stabilization of the Economy and Finance Program" and "Stabilization Measures Plan," issued June 19, 1998. 


\section{Box 1. Key Features of Russia's July 1998 Emergency Financing Package}

The key features of the package were the following:

- $\$ 22.6$ billion in funding ( $\$ 15.1$ billion from the IMF, $\$ 6.0$ billion from the World Bank, and $\$ 1.5$ billion from the Government of Japan), of which $\$ 14.8$ billion was to be received during the second half of 1998 and $\$ 7.8$ billion during 1999 upon completion of fiscal and structural reforms. A total of $\$ 5.5$ billion was actually disbursed: $\$ 4.8$ billion by the IMF, $\$ 0.3$ billion by the World Bank, and $\$ 0.4$ billion by the Government of Japan. These turned out to be the only disbursements under the auspices of the July 1998 package.

-Fiscal reforms to achieve a primary surplus at the federal government level for 1999 of 3 percent of GDP; fiscal targets for 1998 were left unchanged.

- Structural reforms to deal with nonpayments, enhancing competition, intergovernmental fiscal relations, the financial sector, and infrastructure monopolies - in other words, comprehensive reforms to harden enterprise budgets, ensure long-run fiscal sustainability, and create a good climate for private sector development and investment.

-A market-based debt swap designed to convert GKOs into long-term dollardenominated Eurobonds (the GKO-Eurobond swap). This was designed to supplement efforts to move away from domestic debt financing by issuing Eurobonds instead, beginning in early June. (Although not formally a part of the package, the swap was seen by the market as an integral component of the overall financing and restructuring effort.)

The package can be divided into two parts: measures to address confidence or liquidity problems, and measures to address fundamental problems. The confidence-enhancing measures included the $\$ 5.5$ billion foreign exchange injection as well as the attempt to reduce rollover risk through the GKOEurobond debt swap. The measures addressing the fundamentals included structural reforms to help create a good climate for private sector development, with the elimination of nonpayments receiving prominent attention, and fiscal structural reforms designed to place the consolidated fiscal balance on a stable footing. As it turned out, the Duma, which met in a special legislative session held between the announcement of the package on July 13 and the IMF board discussion on July 20, did not approve all the legislation pertaining to the fiscal package. Therefore the first tranche of the IMF funding was reduced from $\$ 5.6$ billion to $\$ 4.8$ billion. 
paper to meet margin calls and partly or completely pay off maturing syndicated loans, panic set in. Depositors sought first to convert their ruble bank deposits into dollar deposits and then to withdraw them altogether, reinforcing the liquidity shortage. On August 14 it was reported in the press that the CBR had intervened to bail out SBS-Agro, one of the two banks with the largest volume of household deposits after the state-owned Sberbank (the other being Inkombank). During that week alone the CBR lost $\$ 1.7$ billion in reserves as portfolio investors exited the equity and GKO markets. A total of $\$ 10.5$ billion had been used to defend the ruble since July 10, far more than the IMF and World Bank tranches received under the emergency package ( $\$ 4.8$ billion on July 21 and $\$ 0.3$ billion on August 7, respectively). This forced the emergency measures of August 17, described at the outset. A further $\$ 2.8$ billion was lost before the ruble was floated on September 2.

\section{Russia's Fundamentals}

Our discussion of the fundamentals of the Russian economy centers on Russia's public debt dynamics over the three years preceding the crisis, during which a stabilization program was implemented with the goal of achieving single-digit inflation by 1997 . We argue that a fundamental policy inconsistency - a continuation of high fiscal deficits coupled with a low-inflation regime induced by fixing the exchange rate-in the end triggered the crisis. The deficit got locked in because of a tacit system of enterprise bailouts in the form of reduced tax and energy payments. These implicit subsidies had the effect of compensating for the adverse impact of the real appreciation and high real interest rates engendered by the stabilization and fiscal policies. These subsidies were embedded in what was called the "nonpayments system." ${ }^{15}$ At first, domestic and foreign banks and portfolio investors eagerly financed the deficit, as Russia's debt was small and there was the promise of rapid growth under the aegis of reform programs supported by the international financial institutions. But with fiscal deficits remaining intractable - in large part because of nonpaymentspublic debt kept growing. A classic fiscal fundamentals crisis was brewing.

15. Pinto, Drebentsov, and Morozov (2000a and b) provide a comprehensive analysis of the nonpayments system; see also Commander and Mumssen (1998). 
The anticipation of a shift to monetization to finance debt service, and hence an abandonment of the fixed peg, triggered the crisis.

This depiction of events echoes results from formal models developed by Paul Krugman, Thomas Sargent and Neil Wallace, Robert Flood and Peter Garber, and Flood and Olivier Jeanne, among others. ${ }^{16}$ These models have several features of note. First, the key determinant of the crisis is an inability to fix the underlying fiscal problem. In Russia, cutting spending and raising tax compliance were part of the package. But, as we shall see below, tax revenue could not be raised, predominantly because of slow growth, which in turn was partly attributable to a real overvaluation of the ruble, and because of the interaction of poor tax effort with the nonpayments system. The second feature of these models is that a speculative attack occurs when government debt reaches an endogenous credit ceiling. High real domestic interest rates-reflecting the risks of devaluation and default, for example-accelerate the timing of an attack because they increase the rate at which nominal debt is accumulated. Hence market signals can be a good guide to how long the market will wait for a reform program to work. Third, the models show that augmenting foreign exchange reserves with new debt to defend a peg while the fundamentals are being corrected may be a risky strategy. To quote Flood and Jeanne, "reserves are expensive window dressing . . . by accumulating them the government behaves as an insolvent household that would try to impress creditors by financing large cash balances with credit card debt." ${ }^{17}$ Thus the dynamics of the public debt, including taxes and growth, domestic real interest rates, and asset transactions such as borrowing for reserves and debt restructuring, are key variables in determining the timing of a fundamentals-based speculative attack.

\section{Public Debt Dynamics}

Public debt dynamics are captured by equation 1 :

$$
\dot{d}=(p d-n d f s)+(r-g) d,
$$

16. Krugman (1979); Sargent and Wallace (1981); Flood and Garber (1984); Flood and Jeanne (2000).

17. Flood and Jeanne (2000, p. 11). 
where $d$ is the ratio of public debt to GDP, $\dot{d}$ is its time derivative, $p d$ is the primary deficit as a ratio to GDP, $n d f s$ is the ratio of nondebt financing sources (such as seigniorage and privatization revenue) to GDP, $r$ is the real interest rate on public debt, and $g$ is the growth rate of real GDP. Russia's public debt dynamics flowed from its stabilization strategy implemented over the roughly three years preceding the crisis. This strategy consisted of fixing the exchange rate, replacing central bank credit to the government with market debt (principally consisting of GKOs, OFZs, and foreign currency Eurobonds), and tightening private sector credit. Fiscal retrenchment lagged behind. This comes out very clearly in table 2, which shows that the mid-1990s targets originally set for the fiscal deficit were consistently exceeded, even as the original inflation targets were largely met in 1996 and 1997. In fact, as noted in the introduction, twelvemonth inflation fell to single-digit levels between February and July 1998, before the August collapse.

Meanwhile, the fiscal deficits had become intractable because of the nonpayments system, which had developed to bail out enterprises unable to cope with the high real interest rates and the real appreciation of the ruble, discussed below. This system enveloped the entire economy, including all levels of government, the energy monopolies, and manufacturing enterprises. It consisted of two parts: the accumulation of arrears, which grew from 15 percent of GDP at the end of 1994 to an estimated 40 percent of GDP at the end of 1998, and a growing resort to nonmonetary transactions. By the summer of 1998, cash collections were as low as 12 to 13 percent on domestic sales for the gas and electricity monopolies, and about 30 percent for the railways. By that year the share of noncash settlements in enterprise sales had increased to 50 to 70 percent, with the largest enterprises at the high end of this range. During the disinflation period from 1995 to mid-1998, noncash settlements accounted for as much as 50 percent of spending by regional governments, and money surrogates and offsets averaged over 20 percent of federal government noninterest spending. Nonpayments distorted the price system and led to substantial implicit subsidies on tax and energy payments for manufacturing enterprises. These implicit subsidies from the energy monopolies to the manufacturers were passed on to the fiscal accounts as these monopolies became delinquent on their own tax payments, leading to a chronic 
Table 2. Targeted and Actual Inflation and Fiscal Deficit, 1995-98

Units as indicated

\begin{tabular}{|c|c|c|c|c|}
\hline \multirow[b]{2}{*}{ Year } & \multicolumn{2}{|c|}{$\begin{array}{l}\text { 12-month inflation rate } \\
\text { (percent a year) }\end{array}$} & \multicolumn{2}{|c|}{$\begin{array}{c}\text { Fiscal deficit } \\
(\text { percent of } G D P)^{\mathrm{a}}\end{array}$} \\
\hline & Target $^{\mathrm{b}}$ & Actual & Target $^{\mathrm{b}}$ & Actual \\
\hline 1995 & 63 & 131 & 6.0 & 5.7 \\
\hline 1996 & 25 & 22 & 4.2 & 8.4 \\
\hline 1997 & 9 & 11 & 3.2 & 7.0 \\
\hline 1998 & 6 & 84 & 2.2 & $5.9^{c}$ \\
\hline
\end{tabular}

Sources: Ministry of Finance and internal IMF reports.

a. Deficit of the federal government on a commitments basis.

b. Targets for 1995 were established by the Stand-By Arrangement with the IMF. For 1996-98 the targets were set as part of a three-year Extended Fund Facility credit. (These were the original program targets, which were later revised.)

c. Excludes overdue interest on GKOs and OFZs.

tax shortfall relative to targets and, hence, ever-rising borrowing requirements. ${ }^{18}$

Table 3 summarizes Russia's public finances and economic growth during this period. Paradoxically, despite negative or slow positive growth, large primary deficits, and sizable interest payments, the ratio of public debt to GDP stayed roughly constant over 1995-97. From equation 1, one would have expected this ratio to be on an explosive path. In particular, using the data in table 3, the debt-GDP ratio should have grown by some 8 percentage points in 1996, and a further 7 percentage points in 1997, to 65 percent. Why did it remain flat?

Table 3. Public Finances and Economic Growth, 1995-98

Units as indicated

\begin{tabular}{|c|c|c|c|c|c|c|}
\hline \multirow[b]{2}{*}{ Year } & \multirow{2}{*}{$\begin{array}{c}\text { Primary } \\
\text { deficit } \\
\text { (percent of } \\
G D P \text { ) }\end{array}$} & \multicolumn{2}{|c|}{ Interest payments } & \multicolumn{2}{|c|}{ Government debt ${ }^{\mathrm{b}}$} & \multirow{2}{*}{$\begin{array}{c}\text { Real GDP } \\
\text { growth } \\
\text { (percent a } \\
\text { year) }\end{array}$} \\
\hline & & $\begin{array}{c}\text { Percent of } \\
\quad G D P\end{array}$ & $\begin{array}{l}\text { Percent of } \\
\text { revenues }\end{array}$ & $\begin{array}{c}\text { Billions of } \\
\text { dollars }\end{array}$ & $\begin{array}{c}\text { Percent of } \\
\quad G D P\end{array}$ & \\
\hline 1995 & 2.2 & 3.6 & 28 & 170 & 50 & -4.0 \\
\hline 1996 & 2.5 & 5.9 & 47 & 201 & 48 & -3.4 \\
\hline 1997 & 2.4 & 4.6 & 38 & 218 & 50 & 0.9 \\
\hline 1998 & 1.3 & 4.6 & 43 & 242 & 77 & -4.9 \\
\hline
\end{tabular}

Sources: Ministry of Finance, Goskomstat, and internal IMF reports.

a. Cash plus noncash basis.

b. Domestic plus foreign, end of period.

18. For details see Pinto, Drebentsov, and Morozov (2000b), who link about 65 percent of the debt increase in 1996 and 1997 to these subsidies. 
Table 4 provides additional information that helps answer this question. The costliest share of public debt at the margin — the GKOs and OFZsgrew quickly, from 10 percent of total public debt in 1995 to 27 percent by the end of 1997. Hence this factor cannot explain why the ratio of public debt to GDP stayed constant. Nor can seigniorage, which fell substantially with declining inflation, although there might have been additional inflation tax gains on the nonmarket portion of the domestic debt ("other domestic" debt in table 4).

The remaining factor is the real exchange rate. The sizable impact of the real appreciation of the ruble, which started in mid-1995 when the exchange rate was fixed and lasted until mid-1997, is demonstrated by replacing $r$, the real interest rate in equation 1, with its expanded version (a derivation is available from the authors upon request): ${ }^{19}$

$$
r=w r_{d}+(1-w)\left(r_{f}-\rho\right),
$$

where $r_{d}$ is the ruble real interest rate, $r_{f}$ is the foreign real interest rate, $\rho$ is the percentage change in the real exchange rate (defined such that $\rho>0$ denotes a real appreciation), and $w$ and $(1-w)$ are the shares, respectively, of ruble and foreign debt in total public debt. Substituting equation 2 into equation 1, it can be seen that a real appreciation reduces the growth of the debt-GDP ratio: $\partial \dot{d} / \partial \rho=-(1-w) d<0$. If the share of foreign debt is high, and if $r_{f}$ is small and $\rho$ positive and sufficiently high, the impact of both high domestic real interest rates and slow growth could be more than offset. For example, using the discrete time version of equation 1 in conjunction with equation 2, the impact of real appreciation in 1996 alone was to lower the ratio of public debt to GDP by 8 percentage points. ${ }^{20}$ The

19. The exchange rate was fixed in the sense that it was managed within the context of tight bounds aimed at keeping the rate of depreciation far less than prevailing inflation, so that the nominal exchange rate became an anchor for stabilizing prices.

20. For this computation, we use the equation $d_{t}-d_{t-1} \equiv \Delta d=\left(p d_{t}-n d f s_{t}\right)+d_{t-1}(r-g) /$ $(1+g)$. For 1996, $(1-w)=0.69, \rho=0.22, d_{t-1}=0.50$, and $g=-0.034$. This gives $\Delta d=-0.08$. Note that $\rho$ is based on the real effective exchange rate shown in figure 2, which is a tradeweighted real exchange rate using the consumer price index as the deflator. Strictly speaking, we should calculate $\rho$ using an arithmetic mean of individual bilateral $\rho \mathrm{s}$, with weights given by beginning-of-period shares in total debt, and using GDP deflators. We calculated such a $\rho$ for 1996 and 1997 using the fact that most Russian foreign debt was denominated in dollars and deutsche marks, and obtained 22 percent and 4.6 percent, respectively, which by coincidence are close to the numbers shown in table 4 . 
Table 4. Interest Rates, Debt Composition, and the Real Exchange Rate, 1995-97 Units as indicated

\begin{tabular}{|c|c|c|c|c|c|c|}
\hline \multirow[b]{2}{*}{ Year } & \multirow{2}{*}{$\begin{array}{c}\text { Real yield } \\
\text { on GKOs } \\
\text { (percent a }^{\text {percar })^{\mathrm{a}}}\end{array}$} & \multicolumn{3}{|c|}{ Debt composition (percent of total) ${ }^{\mathrm{b}}$} & \multirow{2}{*}{$\begin{array}{c}\text { Real exchange } \\
\text { rate } \\
\text { appreciation } \\
\text { (percent) }\end{array}$} & \multirow{2}{*}{$\begin{array}{c}\text { Seigniorage } \\
\text { (percent of }^{(-1){ }^{\mathrm{c}}}\end{array}$} \\
\hline & & $\begin{array}{c}G K O s \\
\text { and } O F Z s\end{array}$ & $\begin{array}{c}\text { Other } \\
\text { domestic }\end{array}$ & Foreign & & \\
\hline 1995 & 99 & 10 & 14 & 76 & 10 & 3.62 \\
\hline 1996 & 58 & 21 & 10 & 69 & 22 & 1.26 \\
\hline 1997 & 14 & 27 & 10 & 63 & 6 & 1.36 \\
\hline
\end{tabular}

Sources: Authors' calculations based on data from Brunswick UBS Warburg, Moscow; internal IMF and Ministry of Finance reports; and Russian Economic Trends, various issues.

a. Average nominal GKO yield adjusted by the inflation target for that year.

b. End of period.

c. Change in nominal base money.

significance is that the apparent stability in the public debt-GDP ratio between 1995 and 1997 was not due to sound fundamentals, but rather to one-shot gains from a real appreciation that could not be expected to continue, and which disguised the rise in nominal debt.

By May 15, 1998, Russia's debt dynamics were increasingly unstable. Growth forecasts had been downgraded to 0 to 1 percent for the year, and GKO auction rates had reached 40 percent. The rest of the macroeconomic program looked as follows: an 8 percent domestic inflation target, a constant real exchange rate target, and a target fiscal deficit of $\$ 25$ billion for 1998 (152 billion rubles under the IMF program) to be financed with $\$ 6$ billion in new Eurobonds at rates of about 12.5 percent and the ruble equivalent of $\$ 19$ billion in domestic debt. Given these parameters, the weighted marginal real interest rate (assuming 2 percent U.S. inflation) was close to 27 percent. $^{21}$

What happened is that, with stabilization substantially achieved by early 1998, and with the CBR aiming for a constant real exchange rate, public debt began to reflect its true underlying dynamics as determined by the primary deficit, high domestic interest rates, a growing reliance on domestic borrowing, and disappointing growth. Based on the marginal cost of borrowing computed above, and the fiscal track record, public debt could have been regarded as being on an explosive path.

21. Using equation 2 and making appropriate substitutions, the marginal real interest rate is given by $(6 \div 25)[0.125-0.02]+(19 \div 25)[0.40-0.08]=0.2684$, or 27 percent . 


\section{Growth}

Rapid growth would have improved Russia's debt dynamics by facilitating higher tax collections while also increasing seigniorage and the demand for public debt. After a cumulative decline in real GDP of 40 percent during 1990-95, there was widespread expectation that Russia would resume growing in 1996. Typical was this quote from the Economist Intelligence Unit: "As the EIU has long been predicting, 1996 is expected to be the year in which Russia finally achieves real GDP growth. ... This opinion is shared by most other forecasters. . .."22 In fact, Russia's pursuit of a rapid reduction in inflation to single-digit levels had been undertaken in the hope that this would lead to the resumption of growth, as had happened in the transition countries of central Europe. ${ }^{23}$

As it turned out, growth expectations were consistently belied. ${ }^{24}$ The first ten months of 1997 held out hope, as inflation and interest rates fell. But insufficient progress on structural reforms, the chronic tax shortfall, and global volatility transmitted from the East Asian crisis starting in October 1997, which inevitably led investors to scrutinize Russia's fundamentals more carefully, dampened prospects. It was becoming plain by mid-1998 that Russia would have to solve its nonpayments problem in order to create a foundation for sustainable growth, and that there were no quick fixes available, as the Kirienko government's own analysis showed in June 1998. Growth for 1998 was initially projected at 1 to 2 percent, but with the wisdom of hindsight, it is clear that there never was a structural foundation for growth to reach the levels required to stabilize the debt dynamics. The inability to achieve growth during 1995-98, despite the very low levels to which output had fallen, was partly the result of an inhospitable macroeconomic environment, featuring high real interest rates and a currency that had appreciated excessively in real terms, as discussed below.

22. EIU Country Report: Russia, 1st quarter 1996.

23. Fischer, Sahay, and Végh (1996).

24. Buckberg and Pinto (1997). For example, the Economist Intelligence Unit's country report on Russia for the first quarter of 1996, page 8, forecast real GDP growth at 3 percent for 1996 and 4 percent for 1997. Actual outcomes, as reported in table 3, were -3.4 percent for 1996, +0.9 percent for 1997, and -4.9 percent for 1998 . 


\section{Real Interest Rates}

As a result of the credit squeeze and heavy public borrowing associated with the stabilization program, real interest rates soared in mid-1995 (figure 1), averaging 56 percent per year based on the average GKO yield between May 1995 and July 1997. ${ }^{25}$ There are three possible reasons why real interest rates remained so high for so long in spite of the fixed exchange rate, hitting enterprises with a "double whammy" of real ruble appreciation and a liquidity squeeze. The first was that macroeconomic policy lacked a track record of credibility, and fiscal deficits remained high, resulting in a high risk premium. The second was the political uncertainty preceding the June 1996 presidential elections, which might have made foreign portfolio investors nervous about increasing their exposure to Russia. ${ }^{26}$ The third reason was that the structure of the GKO market might have led to collusive behavior by the large banks operating as primary dealers, while restrictions on conversion into foreign currency and repatriation of the ruble proceeds of maturing GKOs dampened the enthusiasm of potential foreign investors.

The evidence supports all three possibilities. Fiscal deficits were indeed high and seemingly intractable, justifying concerns about policy credibility, and foreign portfolio inflows were relatively small until 1997, as table 5 shows. Real interest rates in 1996 were at their peak in the months leading up to the 1996 presidential elections, but they came down sharply after Yeltsin finally won in the second round in early July (figure 1). And although informed traders reject the possibility that the GKO market was rigged, nonresident access to the GKO market was not officially permitted until early 1996, and dollar returns were capped through compulsory purchases of currency forward contracts at preset prices. These restrictions were progressively relaxed, and this liberalization might partly explain the boom in foreign participation in 1997, which coincided with reduced political uncertainty and the appointment in early 1997 of an economic "dream team" spearheaded by two young

25. On the credit squeeze for enterprises, see Commander and Mumssen (1998) and Organization for Economic Cooperation and Development (1997).

26. Boris Yeltsin's public approval ratings were at single-digit levels as late as March 1996, with elections scheduled for June. He finally staved off a spirited challenge from the communist party leader, Gennady Zyuganov, winning by a small majority in the second round. 
Figure 1. Real Short-Term Interest Rate, $1995-98^{a}$

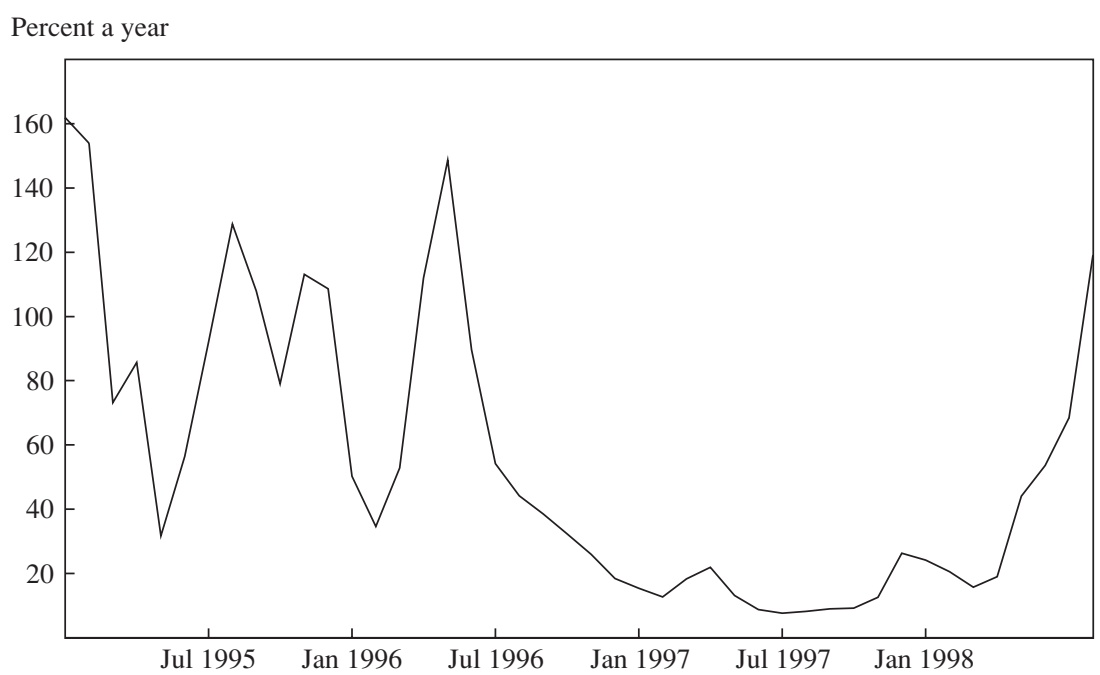

Source: Authors' calculations based on data from Brunswick UBS Warburg, Moscow, and internal IMF data.

a. Average nominal yield on GKOs in the secondary market adjusted by the twelve-month IMF inflation target.

Table 5. Portfolio Capital Inflows, Foreign Exchange Reserves, and the Stock Market, 1995-98

Units as indicated

\begin{tabular}{lccc}
\hline Year & $\begin{array}{c}\text { Portfolio inflows } \\
\text { (billions of dollars) }^{\mathrm{a}}\end{array}$ & $\begin{array}{c}\text { Official reserves } \\
\text { (billions of dollars) }^{\mathrm{b}}\end{array}$ & RTS index $^{\mathrm{c}}$ \\
\hline $1995: 4$ & 0.1 & 17.2 & 82.9 \\
$1996: 1$ & 1.0 & 19.2 & 75.6 \\
$1996: 2$ & 1.7 & 15.9 & 204.1 \\
$1996: 3$ & -0.1 & 15.1 & 165.9 \\
$1996: 4$ & 1.8 & 15.3 & 200.5 \\
$1997: 1$ & 5.9 & 16.5 & 301.3 \\
$1997: 2$ & 8.2 & 24.6 & 418.6 \\
$1997: 3$ & 2.0 & 23.1 & 498.4 \\
$1997: 4$ & 2.3 & 17.8 & 396.9 \\
$1998: 1$ & 4.3 & 16.9 & 325.5 \\
$1998: 2$ & 4.3 & 16.2 & 151.4 \\
$1998: 3$ & 1.0 & 12.7 & 43.8 \\
$1998: 4$ & 0.7 & 12.2 & 58.9 \\
\hline
\end{tabular}

Sources: Central Bank of Russia and the World Wide Web site of the Russian Trading System.

a. Includes purchases of both government securities and equities by foreigners.

b. Gross reserves of the Central Bank of Russia, including gold.

c. Official (ruble-based) index of the Russian Trading System, the stock exchange. 
reformers. ${ }^{27}$ The CBR's foreign exchange reserves soared, as did the stock market as measured by the Russian Trading System index. Restrictions on foreign participation in, as well as repatriation of proceeds from, the GKO-OFZ market were substantially eased by early 1998, and according to investment analysts in Moscow, exit could then occur in a matter of two days.

\section{Real Exchange Rate}

The real exchange rate during the three years preceding the crisis can be regarded as depending on the oil price, on the current account balance and capital flows (the balance of payments), and on the stabilization program. Although it is conventional to think of the real exchange rate as endogenously determined, it may be dominated for a long time by nominal exchange rate policy. ${ }^{28}$ For example, if the government is embarking on a stabilization program and initial debt levels are low, a real appreciation may be supported for several years if real interest rates remain high enough to attract private capital. But when the stock of debt reaches default levels, a sudden, sharp correction may result. We argue here that the Russian stabilization and accompanying high real interest rates were the dominant influence on the real exchange rate before the crisis, leading to a large real appreciation that was sustained until August 17, 1998.

The oil price does not appear to have played a prominent role in the real appreciation before the crisis. For example, even though nominal oil export prices rose by 25 percent in 1996, the terms of trade improved by only 8 percent. However, the sharp decline of oil prices in 1998, leading to a 13 percent deterioration in the terms of trade, probably did contribute to accelerating the speculative attacks in 1998, as it was not reflected in an exchange rate adjustment. Furthermore, oil did not play a significant role in public debt dynamics before the crisis. The link between oil prices and fiscal revenue at the level of the federal government was tenuous, because many of the taxes on oil were specific rather than ad valorem, and oil companies had consistently managed to show low profits, regardless of the

27. Privatization czar Anatoly Chubais was appointed first deputy prime minister and minister of finance, and the reformist governor of Nizhny Novgorod, Boris Nemtsov, was appointed first deputy prime minister and minister for fuel and energy.

28. Dornbusch, Goldfajn, and Valdés (1995) make this point in their study of currency crises. 
price level. In addition, much of the tax revenue from oil was retained at the subnational levels of government. Only when oil export taxes were reintroduced in early 1999 and raised substantially in 2000 as oil prices took off was a strong link established between the primary fiscal surplus at the federal level and oil prices. ${ }^{29}$

At no point did Russia's current account balance reach levels commonly considered dangerous. After a surplus in 1996, the current account deficit in 1997 was less than 1 percent of GDP, and at the end of 1997 rough balance was projected for 1998; this was revised to a deficit of 2 percent of GDP by July 1998, just before the meltdown. ${ }^{30}$ Likewise, the net impact of capital flows is ambiguous, although, ceteris paribus, one would have expected both the current account deficit and capital flight to have put downward, not upward, pressure on the real exchange rate. For example, 1996 was one of the worst years for capital flight, as political uncertainty intensified in the months leading up to the presidential elections. In early 1996 Yeltsin appeared to have little chance of beating communist party leader Gennady Zyuganov in the elections scheduled for June, which were resolved only after a second round in early July. ${ }^{31}$ Gross capital outflows were estimated at $\$ 26.7$ billion, or 7.3 percent of GDP. ${ }^{32}$ However, the reduction in reserves was much smaller, less than $\$ 2$ billion: most of the capital outflows in 1996 were financed by the current account surplus, incoming portfolio flows, and rising public external debt, mainly bilateral and multilateral official borrowings. Thus capital outflows, which would have put downward pressure on the real exchange rate, were largely offset

29. IMF (2000a) attributes the large fiscal improvement in 2000 to discretionary tax policy changes, including, importantly, the reintroduced and expanded export taxes on oil. These factors were either nonexistent or insignificant in the precrisis period. Thus, falling oil prices aggravated macroeconomic instability in 1998 but did not fundamentally determine public debt dynamics.

30. In principle, there is nothing sacrosanct about the level of the current account balance in relation to an overvaluation. A country may be running a surplus but still have a real overvaluation if, for example, the surplus is not enough to meet external transfers.

31. The General Accounting Office (2000, p. 46) notes that targets under the IMF program were frequently modified in the months preceding the 1996 elections “. . . because of unexpected events, especially the large capital outflow in advance of the presidential elections that made those targets unattainable."

32. The basic equation is as follows: current account surplus + foreign portfolio investment + government external borrowings $=$ increase in CBR gross reserves + capital outflows. For 1996 the current account surplus was $\$ 11.8$ billion (on a cash basis), portfolio investment $\$ 4.5$ billion, government borrowing $\$ 8.6$ billion, and CBR reserves fell by $\$ 1.9$ billion. 
by the capital inflows needed to finance the fiscal deficit, by portfolio inflows into the stock market, and by the current account surplus. ${ }^{33}$ Hence we would have to conclude that the main factor influencing the real exchange rate was macroeconomic policy, and in particular the exchange rate-based stabilization.

Figure 2 illustrates the impact of stabilization on the real exchange rate. In December 1995, inflation for the preceding twelve months was 131 percent - a substantial reduction from 200 percent in 1994, but far greater than the 31 percent nominal depreciation of the ruble against the dollar over the same period. This appears to be a standard fate of exchange rate-based stabilizations, as inflation comes down much more slowly than the currency depreciates. ${ }^{34}$ Just as real interest rates were coming down in 1997 on the basis of substantial portfolio inflows from abroad, the ruble started slowly appreciating again in real terms. It sustained its late-1997 level until August 17, 1998, as the government stuck to its stabilization goals and raised interest rates to defend the ruble.

Rudiger Dornbusch and Alejandro Werner note that a real appreciation can be considered an equilibrium phenomenon under three conditions: when it coexists with increasing efficiency in the traded goods sector and prospects of growth; when a boom in asset prices translates into higher investment; and when everybody wins-real wages go up, growth is strong, tax receipts increase, and interest rates come down..$^{35}$ None of these conditions was fulfilled in Russia's case. Quite the opposite: this was exactly the time when hidden subsidies through nonpayments were pro-

33. A caveat: as Loungani and Mauro (2000) note, capital flight estimates for Russia are bedeviled by the poor quality of balance of payments statistics, which lead to a variety of estimates (and definitions). Two possibilities cannot be ruled out. The first is that the trade surplus, and hence capital flight, are both overestimated. The second is that round tripping, that is, flight capital returning in the guise of foreign portfolio investment, occurred, for example to take advantage of high GKO yields. (This is a more plausible argument than to assert that ignorant foreigners were bringing money in while informed Russians were taking it out.) An example of round tripping would be an oil company underinvoicing its exports to evade taxes, and then creating a foreign shell company to invest in GKOs as a nonresident.

34. Dornbusch and Werner (1994); Dornbusch, Goldfajn, and Valdés (1995). Summing up lessons from past exchange rate-based stabilizations, Dornbusch and Werner (1994) warn that "... almost without exception, a fixed rate will not imply zero inflation. . . . there is a need to assess very quickly when to abandon the fixed rate and settle for some inflation, though at a far more moderate rate than before the stabilization." They note that the Chilean authorities, learning from their unsuccessful experience in the 1970s, ". . . never made inflation the absolute and exclusive target" in the 1980s.

35. Dornbusch and Werner (1994). 
Figure 2. Real Effective Exchange Rate, 1995-99a

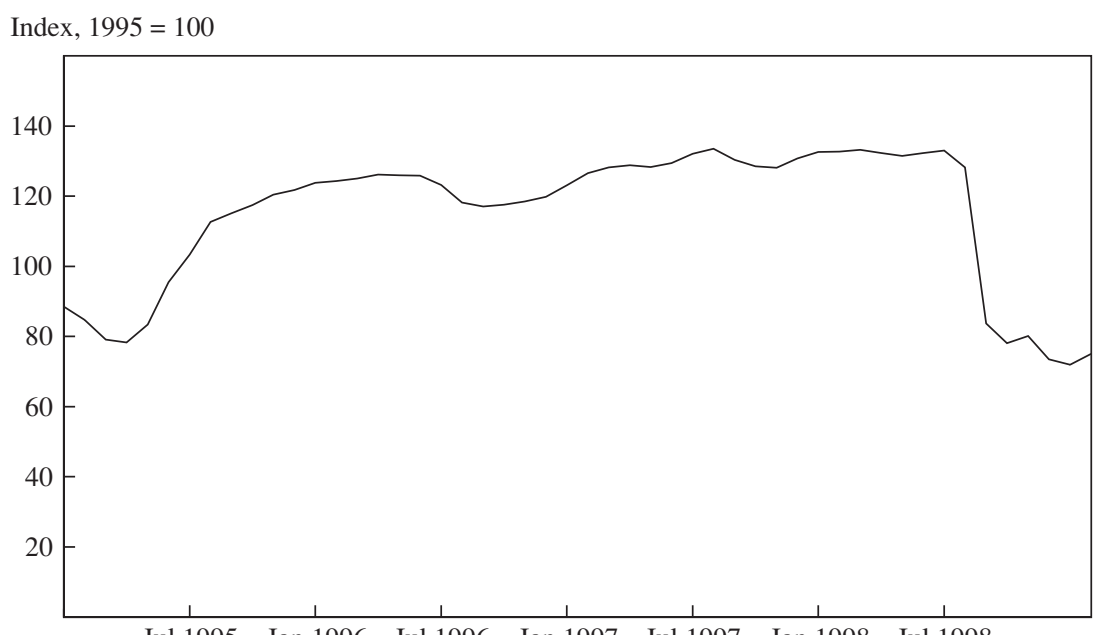

Jul 1995 Jan 1996 Jul 1996 Jan 1997 Jul $1997 \quad$ Jan 1998 Jul 1998

Source: IMF, International Financial Statistics.

a. Ratio of Russian CPI to the product of trading partners' trade-weighted CPI and exchange rate.

liferating, diluting incentives for enterprise restructuring. Further, even though the stock market boomed, investment did not take off; instead, asset stripping and capital flight accelerated. ${ }^{36}$ In particular, real appreciation was not associated with credible fiscal and structural reforms. ${ }^{37}$ The strongest proof that the real exchange rate had become a barrier to growth is provided by what happened after the crisis: the real devaluation associated with the meltdown has given domestic industry a huge boost and improved enterprise finances. ${ }^{38}$

36. See, for example, Blasi, Kroumova, and Kruse (1997); Black, Kraakman, and Tarassova (2000).

37. General Accounting Office (2000, pp. 120-24) describes the inadequate implementation of reforms designed to address budgetary imbalances and create a good climate for private sector development in the precrisis period. It also notes (p. 45) that "Russia did succeed in bringing inflation under control in 1995 in part due to the government's adoption of an exchange rate band."

38. For a discussion of the impact of the postcrisis real depreciation, see Ahrend (1999). Noting the strong output, balance of payments, and fiscal rebound after the crisis, IMF (2000a, p. 4) asserts that "The strong macroeconomic performance reflects mainly the large real ruble depreciation in 1998, but also the increase in oil prices in world markets and a significant strengthening of fiscal and monetary policies." 


\section{Market Signals}

\section{The External Debt Market}

In June 1998, in keeping with the Kirienko government's analysis, which held that the predominance of costly, short-term GKOs in new borrowings was contributing to financial crisis, the Russian authorities began a program to shift back toward external debt. In fact, $\$ 32.7$ billion worth of domestic debt (GKOs and OFZs, including OFZ coupons) was scheduled to mature over the last seven months of 1998 (table 6). The idea was that these could be replaced with foreign debt at lower nominal interest rates from the international financial institutions and through market borrowings.

In the runup to the negotiations over the July emergency financing package, various recommendations were put forward on the size of such a package. Box 2 presents some of these estimates in chronological sequence. These estimates focused largely on Russia's liquidity needs over the short term, not on the fiscal fundamentals. They implicitly assumed that a devaluation would be bad, that there was a confidence crisis, and that Russia faced a flat supply curve for dollars. Hence acquiring more dollar reserves would be a good thing, as this would enable holders of costly GKOs to exit upon maturity, while offering comfort that dollar obligations could also be serviced. What was missed was that any such augmentation of reserves would mean an increase in public debt at a time of weak fiscal fundamentals. How would the market take this?

As it turned out, the marginal interest rate on Russian external debt was already high and rising (table 7). In June 1997 Russia had issued ten-

Table 6. Value of Maturing GKOs and OFZs, June-December 1998

Billions

\begin{tabular}{lcc}
\hline Month & Rubles & Dollars $^{\mathrm{a}}$ \\
\hline June & 31.9 & 5.1 \\
July & 37.9 & 6.1 \\
August & 28.5 & 4.6 \\
September & 36.6 & 5.9 \\
October & 28.9 & 4.7 \\
November & 25.4 & 4.1 \\
December & 13.4 & 2.2 \\
Total & 202.6 & 32.7 \\
\hline
\end{tabular}

Sources: Author's calculations based on internal Ministry of Finance data and IMF, International Financial Statistics. a. Converted at 6.20 rubles to the dollar, the exchange rate at the end of June. 
Table 7. Yield Spreads on Russian Eurobonds upon Issue, 1997-98

Units as indicated

\begin{tabular}{lccc}
\hline Issue date & Maturity date & $\begin{array}{c}\text { Yield spread } \\
\text { (basis points) }^{\mathrm{a}}\end{array}$ & $\begin{array}{c}\text { Face value } \\
\text { (billions of } \\
\text { dollars) }\end{array}$ \\
\hline June 26, 1997 & 2007 & 375 & $2.40^{\mathrm{b}}$ \\
June 4, 1998 & 2003 & 650 & 1.25 \\
June 18, 1998 & $2028(2008)^{\mathrm{c}}$ & 753 & 2.50 \\
July 24, 1998 & 2005 and 2018 & 940 & 6.44 \\
\hline
\end{tabular}

Source: Ministry of Finance.

a. Over U.S. Treasury securities of similar maturity.

b. Of which $\$ 0.4$ billion was settled on October 28 at a yield spread of 334 basis points.

c. Issued as a thirty-year bond with a put-at-par option after ten years.

d. Seven- and twenty-year bonds issued as part of the GKO-Eurobond swap.

year Eurobonds at 375 basis points over comparable U.S. Treasuries. A year later, as part of its ruble defense strategy, Russia issued $\$ 1.3$ billion worth of five-year Eurobonds at a spread of 650 basis points. Only a few days thereafter, on June 18, 1998, Russia issued additional Eurobonds at a substantially higher 753 basis points over Treasuries. And the July 24 Eurobond issued as part of the GKO exchange was priced at a spread of 940 basis points - another substantial increase, at a yield of over 15 percent. These numbers indicate that Russia was facing a steeply rising marginal supply curve for its external debt and probably could not have raised the sort of sums described in box 2 without triggering a disruption in the market for its external debt.

As a benchmark for default risk, it is worth noting that on June 10, 1998, the spread on the Russian ten-year Eurobond was 100 basis points below that of Indonesia, which was in the throes of its own economic and political crisis. By June 25, however, the spreads were equal. On July 24, when the GKO-Eurobond swap was completed, Russian spreads were 160 basis points above Indonesia's. ${ }^{39}$

\section{The Domestic Debt Market}

The domestic debt market was also indicating growing default and devaluation risk, starting in May 1998. Equation 3, which is an expanded form of the familiar interest rate parity equation, shows how the domestic

39. These spreads were measured with reference to the benchmark 10 percent coupon Russian Eurobond issued in 1997, maturing July 26, 2007, and Indonesia's benchmark 7.75 percent coupon Eurobond issued in 1996, maturing August 1, 2006, from Datastream. 


\section{Box 2. Contemporary Estimates of Required Financing Package for Russia}

June 11, 1998

An Oxford Analytica report concluded by saying: "The government is not wellplaced to defend the rouble with only vague promises of international support. The G7/IMF could restore confidence by announcing a stabilisation fund of at least 5 billion dollars - a fund which Russia would be highly unlikely to draw on." (Oxford Analytica, "Russia: Devaluation Threat," Oxford Analytica Brief, June 11, 1998.)

June 17, 1998

The Moscow Times quoted one expert as follows: " If global risk premiums remain stable, $\$ 10$ billion should provide Russia several months to re-establish confidence in its credit fundamentals,' said Eric Fine, debt analyst at Morgan Stanley in London. He cautioned, however, that if the worldwide slump continues, the figure could be as high as $\$ 40$ billion." (Sujata Rao, "News of IMF Delegation's Visit Boosts Market,” Moscow Times, June 17, 1998.)

June 23, 1998

Writing in the Financial Times, Martin Wolf mentioned the need for ". . . a at least the $\$ 10$ bln- $\$ 15$ bln the Russians are asking for-ideally more," based on the idea that Russia faced high devaluation risk, but that default was out of the question, and (implicitly) that the real exchange rate was in equilibrium. (Martin Wolf, "Russian Knife-Edge_-The West Should Provide Funds to Help Save the Ruble. If It Does Not, Russian Reforms Will Be Set Back for Years," Financial Times, June 23, 1998.)

June 26, 1998

Reuters reported: "Another billion dollars here or there from reserves-backed loans would not change Russia's position and could hurt its name. 'Anything

interest rate can be decomposed to give estimates of default risk and devaluation risk. ${ }^{40}$

$$
i_{d}=i_{f}+S R P+(d x / x)^{*}+D R P
$$

40. This is a variant of a decomposition originally made by Frankel and MacArthur (1988). An implicit assumption is that GKOs and the 2001 dollar Eurobond (the closest in maturity to the one-year GKO) had the same default risk. After the crisis, Eurobonds were treated as senior to GKOs, which means that part of what is measured as the devaluation risk 
like this is just piecemeal and it is not going to restore confidence,' said Peter Boone, co-director of research at Moscow investment bank BrunswickWarburg. 'You need at least $\$ 10$ billion and signals that more is coming and more is available if needed,' he said, referring to hopes of a $\$ 10$ billion- $\$ 15$ billion IMF package. 'Small amounts of money just go into reserves . . . you just allow a few more investors to convert their money out at the current exchange rate. But you don't solve the underlying problem.' " (Peter Henderson, "Russia Needs Aid from IMF, Not Pawn Shop," Reuters, June 26, 1998.)

\section{July 7, 1998}

Arguing strongly against the devaluation of the ruble, Anders Åslund suggested $\$ 10$ billion from the World Bank and the IMF, plus a few billion dollars from Eurobonds, to deal with the "about $\$ 25$ billion of treasury bills held by Russian commercial banks and foreign investors, while the international reserves hover around \$15 billion." (Anders Åslund, "Don’t Devalue Ruble," Moscow Times, July 7, 1998.)

\section{July 8, 1998}

The Moscow Times reported: “Moody's Investors' Service, a credit rating agency, said Tuesday that Russia may need up to $\$ 20$ billion to convince investors of its ability to meet its debts. '. . Probably $\$ 15$ billion to $\$ 20$ billion is needed to give the market confidence in Russia rolling over its debt,' David Levey, managing director and co-head of sovereign risk, was quoted by Reuters as saying. Economists say Russia would not necessarily need to spend the loan but would hold it in reserve to restore investor confidence in the ruble." (Jeanne Whalen, "Chubais Says Russia Close to IMF Deal," Moscow Times, July 8, 1998.)

where $i_{d}$ is the domestic interest rate and $i_{f}$ is a base risk-free rate, for example the yield on one-year U.S. Treasury bills; SRP is the sovereign risk premium and captures default risk; $(d x / x)^{*}$ is the target rate of devaluation of the currency against the U.S. dollar; and DRP is the devaluation risk premium, or the compensation for the risk of actual devaluation exceeding the target rate. In our analysis, for the domestic interest rate $\left(i_{d}\right)$ we use the

premium in equation 3 is the wedge between default risk on the 2001 Eurobond and that on GKOs. If we treat this as a constant, equation 3 still gives a good idea of the trend. 
one-year GKO auction rate. For the base risk-free rate $\left(i_{f}\right)$ we use the yield on the one-year U.S. Treasury bill. This rate was fairly steady at about 5.5 percent over the period in question, and therefore the base rate is assumed fixed at that rate. ${ }^{41} \mathrm{We}$ proxy the sovereign risk premium by the spread of the market yield of the Russian 2001 dollar Eurobond, with a 9.25 percent coupon, over that of the comparable 2001 U.S. Treasury note with a 6.25 percent coupon. We calculate the target devaluation rate as follows. The ruble-dollar exchange rate at the start of 1997 was 5.55 rubles to the dollar, and it was anticipated that the exchange rate at the end of the year would be at the midpoint of the announced band of 5.75 to 6.35 to the dollar. This gives a target devaluation rate of 9 percent. For 1998, the CBR announced its aim to maintain a constant ruble-dollar real exchange rate. Given an 8 percent inflation target and U.S. inflation at about 2 percent, this gives a target nominal devaluation rate of 6 percent for 1998. Finally, the devaluation risk premium is obtained as a residual.

Figure 3 shows that both devaluation risk and default risk started to rise in November 1997, coinciding with the spread of the Thai crisis to Korea and other Asian markets. The default risk premium then declined somewhat, only to increase once again toward the end of January 1998. Thereafter the situation appeared to calm down until mid-May, when the final speculative attack began. Table 8 shows our estimates of the sovereign risk premium and the devaluation risk premium for key dates between May 15 and the meltdown. It shows that devaluation risk had become acute by July 13 , and even though it more than halved after the announcement of the international package on that day, it nevertheless remained well above its level on May 15, when the speculative attack started. Default risk meanwhile barely budged, indicating market skepticism about the package and concern about the total volume of debt. Both risk premiums jumped on July 24, when the GKO-Eurobond swap was settled, and continued rising as the speculative attack intensified, leading to the events of August 17, 1998. It is significant that the default risk premium (measured by the spread on the 2001 Eurobond) resumed growing strongly upon completion of the GKO-Eurobond swap, despite the expectation that the swap would improve the short-run debt dynamics.

41. The volatility and level of the yield on the one-year U.S. Treasury bill are so low in comparison to the one-year GKO that this is a conservative assumption. 
Figure 3. Sovereign Risk and Devaluation Risk Premiums, 1997-98

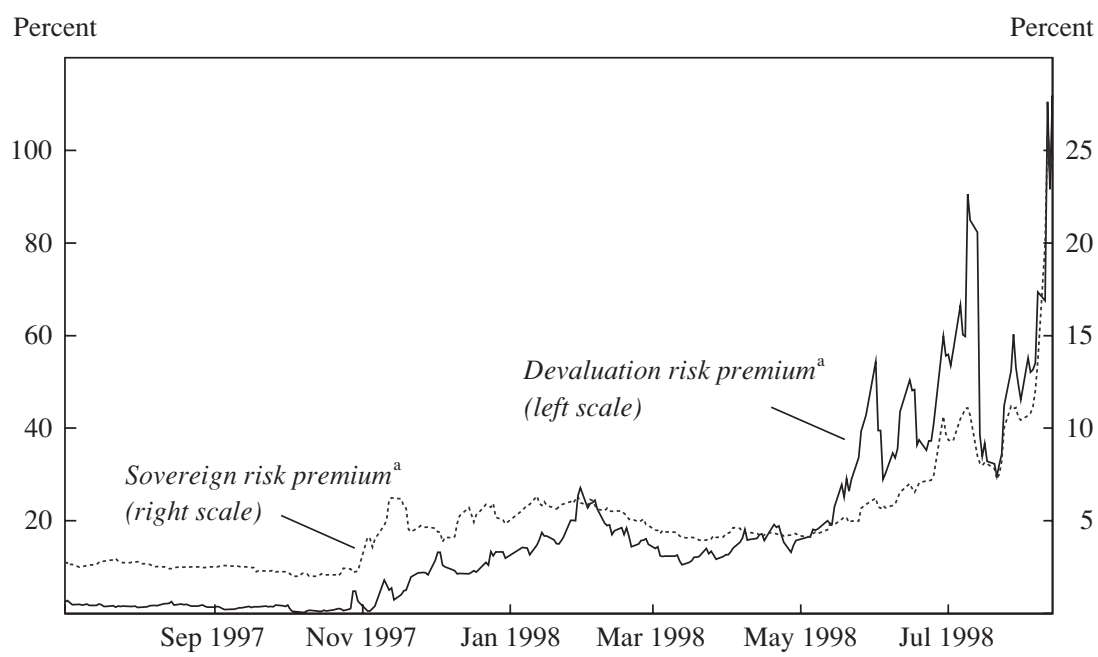

Source: Authors' calculations based on data from Brunswick UBS Warburg, Moscow.

a. See text for definitions.

\section{Issues of Crisis Timing}

In theoretical models that assume perfect foresight, a crisis (defined as the forced switch from a fixed to a floating exchange rate) occurs when the size of the desired portfolio shift out of domestic currency into foreign currency exactly equals foreign exchange reserves, exhausting reserves

Table 8. Sovereign Risk and Devaluation Risk Premiums for Selected Dates in 1998

Percent a year

\begin{tabular}{lccc}
\hline Date & Yield on GKOs & $\begin{array}{c}\text { Sovereign risk } \\
\text { premium }^{\mathrm{a}}\end{array}$ & $\begin{array}{c}\text { Devaluation risk }^{\text {premium }} \\
\text { prem }^{\mathrm{a}}\end{array}$ \\
\hline May 15 & 39.3 & 4.8 & 23.0 \\
July 13 & 102.3 & 8.5 & 82.3 \\
July 14 & 58.2 & 8.1 & 38.6 \\
July 20 & 51.6 & 7.8 & 32.3 \\
July 23 & 54.2 & 8.2 & 34.4 \\
July 24 & 66.4 & 10.0 & 44.9 \\
August 6 & 77.7 & 12.0 & 54.1 \\
August 10 & 99.0 & 20.0 & 67.5 \\
August 14 & 144.9 & 23.8 & 109.5 \\
\hline
\end{tabular}

Source: Authors' calculations based on data from Brunswick UBS Warburg, Moscow.

a. See text for definitions. 
instantaneously and avoiding a jump in the exchange rate. The currency then depreciates at a steady-state rate equal to the inflation rate needed to finance the fiscal deficit through the inflation tax. In the real world, it is impossible to pinpoint when a switch to a float will occur. Here we look at three factors that were key to the timing of the Russian exchange rate collapse: liquidity, bank vulnerabilities, and the July 1998 GKO-Eurobond swap.

\section{Liquidity}

The ratio of short-term debt to reserves is commonly used to gauge a country's vulnerability at times of macroeconomic volatility. ${ }^{42}$ One variable that received considerable attention in the lead-up to the Russian crisis was the ratio of GKOs held by foreign investors to the CBR's reserves. The gap between maturing debt and reserves explicitly or implicitly underpinned the estimates of the necessary financing package, as suggested by the quotations in box 2. However, given widespread currency substitution as well as the history of exchange rate crises in Russia (for example, in late 1994), any hint of crisis would probably be followed by a wholesale shift into dollars, including from cash rubles and bank accounts. ${ }^{43}$

Table 9 therefore presents two measures of liquidity in Russia. We call the first measure a comprehensive liquidity index (CLI) and define it to include broad money (including foreign exchange-denominated bank deposits) plus the market value of GKOs, divided by the CBR's foreign exchange reserves including gold. The second measure is the limited liquidity index (LLI), the measure on which attention focused prior to the crisis; this is defined as the ratio of the market value of GKOs held by nonresidents to CBR reserves. The reason for taking the market value, and not the face value, of GKOs is that the former is more relevant at a time of exit: fleeing investors dump their GKOs in the secondary market, convert the proceeds into dollars, and leave. These liquidity measures capture the two opposing effects of interest rate policy. Raising interest rates to defend the ruble would lower the liquidity indexes by reducing the market value of the outstanding stock of GKOs (a smaller numerator), but it would also worsen public debt dynamics in the face of persistent

42. IMF (2000b).

43. On "Black Tuesday," October 11, 1994, the ruble dropped by 27 percent against the dollar, although it quickly recovered. See Åslund (1995, pp. 205-07). 
Table 9. Alternative Measures of Liquidity, 1996-99

\begin{tabular}{lcc}
\hline Date $^{\mathrm{a}}$ & Comprehensive liquidity index $^{\mathrm{b}}$ & Limited liquidity index $^{\mathrm{c}}$ \\
\hline $1996: 1$ & 4.1 & 0.28 \\
$1996: 2$ & 5.7 & 0.50 \\
$1996: 3$ & 6.4 & 0.65 \\
$1996: 4$ & 6.9 & 0.77 \\
$1997: 1$ & 6.8 & 0.80 \\
$1997: 2$ & 5.2 & 0.62 \\
$1997: 3$ & 5.9 & 0.76 \\
$1997: 4$ & 7.4 & 0.95 \\
$1998: 1$ & 7.8 & 1.08 \\
May 31, 1998 & 8.6 & 1.08 \\
June 30, 1998 & 7.6 & 0.94 \\
July 17, 1998 & 9.3 & 1.19 \\
July 24, 1998 & 6.2 & 0.72 \\
August 14, 1998 & 7.2 & 0.73 \\
1999 & 3.4 & $\ldots$
\end{tabular}

Source: Authors' calculations based on data from Central Bank of Russia and Brunswick UBS Warburg, Moscow.

a. Quarterly and yearly data are end of period.

b. Ratio of market value of GKOs plus broad money to foreign exchange reserves.

c. Ratio of market value of GKOs held by nonresidents to foreign exchange reserves. It is assumed that 30 percent of GKOs are held by nonresidents.

fiscal deficits (a rising numerator over time). At the same time, if interest rates were not raised enough, exit might continue, draining reserves.

Table 9 shows a deteriorating trend in both measures throughout 1996, and then again starting in the fourth quarter of 1997, reflecting growing domestic debt to fund continued fiscal deficits, and falling reserves as these were used up to defend the fixed peg. The indexes rose further in 1998, with the CLI reaching 8.6 by the end of May, indicating that a portfolio shift of less than 12 percent out of domestic assets would have exhausted reserves. At that point the debt restructuring strategy was launched. As already noted, two Eurobonds were issued in June for a total of $\$ 3.8$ billion, and weekly auctions of GKOs were cancelled. An IMF tranche of $\$ 670$ million was also received. This led to a temporary improvement in June, but the CLI then resumed rising as investors converted the proceeds of maturing GKOs and OFZs into dollars. ${ }^{44}$ By July 17 the CLI had reached 9.3 and the LLI stood at 1.19, their highest levels since the beginning of 1996.

44. With the numerator of the CLI much larger than the denominator, and with an exit from the GKO market meaning an equal absolute reduction in both, the ratio rose; that is, liquidity worsened. 
The injection of $\$ 4.8$ billion from the IMF on July 20, as part of the package, and the completion of the GKO-Eurobond swap on July 24 improved liquidity considerably. After July 24 , however, exit from the GKO market intensified and interest rates rose, in a trend that continued until the August 17 crisis. This is captured by the rise in the CLI from 6.2 on July 24 to 7.2 on the eve of the crisis; the LLI, however, shows only a minor variation as the market value of GKOs was shrinking as fast as reserves. This sequence of events indicates that adverse fiscal fundamentals had resumed dominance. If the market was skeptical about the decisive implementation of fiscal and structural reforms, the benefit of lengthening maturity under the swap would be outweighed by the burden of more senior debt on fiscal balances, and this may have prompted exit from the remaining GKOs so soon after the swap. Only the devaluation and restructuring of domestic debt after the crisis proved effective in bringing the CLI down to levels approximating those of 1996; it reached 3.4 by the end of 1999 .

\section{Vulnerable Banks}

The large Moscow banks, which have been the focus of attention in the Russian crisis, had large exposures to the government debt market. These banks differ from their counterparts in the more advanced transition countries of central Europe in three respects. First, they have typically had limited links to the real sector, a factor that contributed to the unexpectedly quick rebound in output after the 1998 crash. Second, they tended to develop as part of segmented financial-industrial groups, which typically coalesced around large natural resource companies; this kind of structure encouraged connected lending. Third, these banks have enjoyed extraordinary political clout. Their influential position contributed to the way in which these banks initially made their money: designated as "authorized banks" for treasury operations, they received what amounted to interest-free loans at a time of high inflation and devaluation and, subsequently, high real interest rates. Their political connections also allowed them to perpetuate their wealth through the notorious "loans-for-shares" privatization auctions in 1995-96, and even in the wake of the crash, it has enabled them to delay the restructuring of the banking sector. ${ }^{45}$

45. Black, Kraakman, and Tarassova (2000) provide one account of how the large Moscow banks made their money. In the loans-for-shares scheme, carried out in late 1995, lending by the Russian banks to the government was collateralized with the shares of 
Ex ante assessments of banks' portfolios were made difficult by the unreliability of published accounting data ${ }^{46}$ Nevertheless, the banks' vulnerability to a deteriorating macroeconomic environment became obvious after the first contagion episode in late 1997, and stemmed from their involvement in the government debt market. ${ }^{47}$ Russian banks were vulnerable to default risk, owing to their heavy investments in government debt (GKOs, OFZs, Eurobonds, and MinFins). They were also exposed to devaluation risk, on account of their having sold dollars forward to nonresident investors in the GKO market, and because of currency mismatches fueled by the exceptionally high interest differential between the end of 1994 and early 1997 (banks had borrowed in foreign currency overseas and invested in ruble treasury bills). And they were vulnerable to rollover risk on syndicated loans extended by foreign banks as well as margin calls on repo operations collateralized with MinFins.

Given the banks' exposures, the raising of interest rates to defend the ruble combined with growing default risk toward the end of 1997 to depress the market value of their portfolios. This made them vulnerable to rising margin calls and potential refusals by foreign banks to roll over loans. Either of these actions would have forced the Russian banks to sell liquid assets - their holdings of government debt-at a loss, further depressing the price of that debt and possibly setting off a downward spiral. Moreover, the need to raise dollars to meet margin calls and repay syndicated loans in part or in full would deplete the CBR's reserves. Another

valuable companies in the oil, metals, and telecommunications industries. The size of these loans was determined in auctions that were not transparent and are suspected to have been rigged (see Lieberman and Veimetra, 1996). Boris Sinegubko ("A Chance to Start Over? Sacrificing Banks May Be the Lowest Cost of Structural Adjustment," Brunswick Warburg, August 21,1998) provides an excellent, detailed analysis of the weakness of the banking system and an early quantification of postcrisis balance-sheet and off-balance-sheet losses. John van Schaik ("Russia: The Newly-Wed and the Nearly Dead," Euromoney, June 1999, pp. 254-63) reports the results of a postcrash audit, based on international accounting standards, of eighteen large banks. Tompson (1997) describes how the role of Russian banks, once regarded as in the vanguard of the movement toward markets, in fact differed little from that of their Soviet-era counterparts.

46. Sinegubko, "A Chance to Start Over?"; van Schaik ("Russia: The Newly-Wed and the Nearly Dead") quotes an auditor as saying that some banks had inflated their capital by 50 to 80 percent.

47. CA IB Investment Bank ("Riding out the Storm," Sector Report: Banking Update, Russia, December 1997, p. 10) describes the banks' situation following the first contagion episode in late 1997 and argues that "... Russian banks should still be considered sovereign risk for all practical purposes." 
exposure stemmed from contracts in which the banks sold dollars forward to nonresident holders of GKOs. Although the precise volume of these forward contracts was not known, it was believed to be substantial enough to cause a banking crisis in the event of a devaluation. ${ }^{48}$ Thus the banks also had an incentive to attack the CBR's reserves.

What about the possibility of a bank bailout contributing to crisis? In East Asia the banks' problems arose from private debt, as banks suffered from exposure to corporations hurt by rising interest rates or from losses built up as a result of risky investments; the banks' difficulties then created quasi-fiscal deficits through the presence of explicit or implicit deposit insurance. ${ }^{49}$ As already noted, Russian banks had limited exposure to the real sector, and the standard welfare concerns associated with the losses of small depositors did not seem applicable, in that about 75 percent of household deposits were held by the state-owned savings bank, Sberbank, under an implicit deposit guarantee. Moreover, household deposits in Russia just before the crisis were only on the order of 7 percent of GDP, compared with over 30 percent in East Asia, owing to widespread currency substitution and hoarding of cash. ${ }^{50}$ As it turns out, the amount spent so far to prop up Russia's banks, including emergency loans to large banks before the meltdown, has been estimated at no more than 2 percent of 1998 GDP. Amounts of this magnitude would not have materially affected the debt dynamics described above. This compares with public bailouts of over 10 percent in Hungary in the early 1990s, and a multiple of that figure in the Asian crisis countries.

However, the banks did not go neglected. Vladimir Potanin, a former deputy prime minister and head of Uneximbank, told reporters in early November 1998 that the bankers knew by August 14, 1998, that the ruble was going to be devalued on August 17. Apparently they persuaded the

48. The ex post audit reported in van Schaik ("Russia: The Newly-Wed and the Nearly Dead") found that, of the capital shortfall of the surveyed banks (which amounted to 115 percent of their assets in the base case), 34 percent came from loan losses, 28 percent from losses on currency forward contracts, and 13 percent from losses on GKOs as of September-October 1998. However, it cannot be ruled out that loans were made to related companies to invest additional amounts in GKOs in order to circumvent exposure limits on security holdings.

49. This is the moral hazard argument of Dooley (1998); Burnside, Eichenbaum, and Rebelo (1999) and Kharas and Mishra (2001) discuss the role of prospective fiscal deficits caused by implicit bailout guarantees to banks in the context of the Asian crisis.

50. Sinegubko, "A Chance to Start Over?" 
prime minister to include a ninety-day foreign debt moratorium (on principal and on margin calls relating to currency forward contracts and repos) as part of the package. ${ }^{51}$ Further, the ruble, which was floated after September 2, 1998, showed a strong tendency to appreciate around the 15th of the month in September, October, and November of that year, dates on which maturing currency forward contracts tended to bunch, thereby minimizing losses for the banks on their short dollar positions (figure 4).

Even when the macroeconomic situation worsened after May 15, 1998, it was believed that any devaluation would be postponed until at least November 15, because most of the currency forward contracts of the influential Moscow banks would have matured by then. We argue next that the main factor that brought the crisis forward to August 17 was the GKOEurobond swap in conjunction with the substantial exposures of the Moscow banks to exchange rate and interest rate risk.

\section{Debt Restructuring: The GKO-Eurobond Swap}

One of the main features of the Russia package was the associated offer of a voluntary, market-based exchange of GKOs for dollar-denominated Eurobonds on July 13, 1998, the same day that the agreement with the international financial institutions was announced. This offer had the following broad parameters and mechanics. First, all GKOs maturing before July 1, 1999, were eligible; these had a total face value of $\$ 39.3$ billion and a market value of $\$ 32.3$ billion at prevailing exchange rates. Second, the Ministry of Finance announced a buyback price for each GKO series, offering a premium over the market price for maturities falling due over the seven weeks to September 9, 1998. ${ }^{52}$ The total buyback value of eligible GKOs was $\$ 33.6$ billion. However, the CBR and the state-owned savings bank, Sberbank, were excluded from participating; when their holdings (believed to be 60 percent of the total) are excluded, the buyback value falls to $\$ 13.4$ billion. Third, ruble buyback prices were to be converted into dollars using the average ruble-dollar rate on trades on the Moscow Interbank Foreign Currency Exchange over July 14 to 17, 1998.

51. Reported in Brunswick Warburg, Daily News Review, November 6, 1998.

52. The ministry offered to buy these series back at par, which implied a premium in that GKOs are discounted treasury bills - the market value can never exceed par at positive discount rates. Thus the ministry's main concern over the following seven to eight weeks appeared to be liquidity. 
Figure 4. Nominal Exchange Rate, September-November 1998

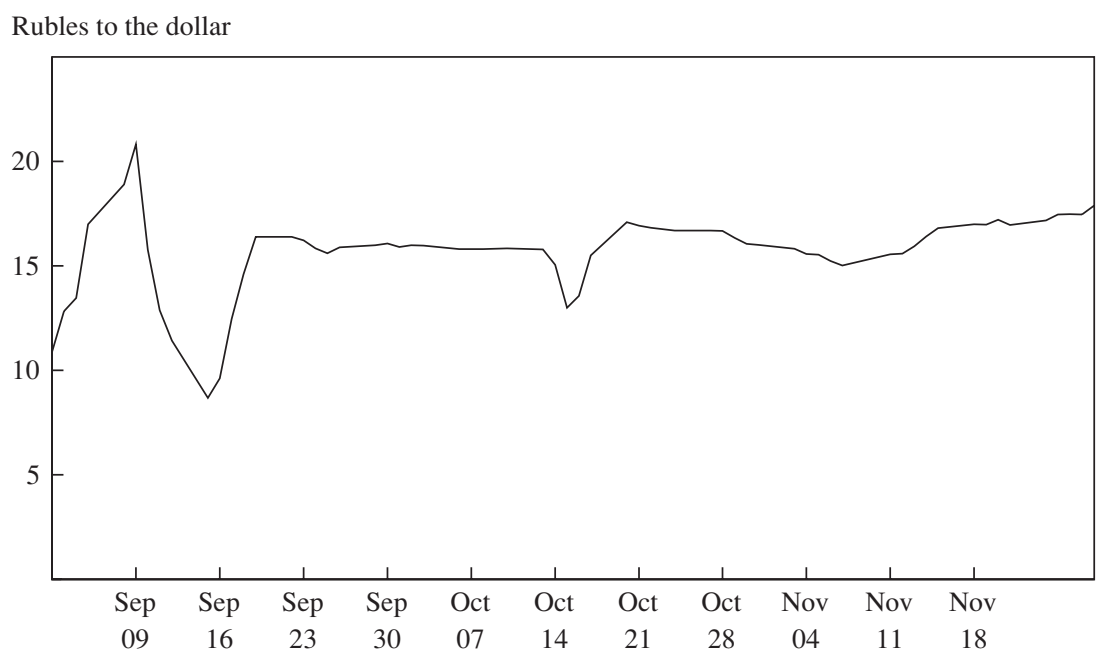

Source: Central Bank of Russia.

Fourth, those wanting to convert would receive equal amounts by market value of seven- and twenty-year dollar Eurobonds. They were asked to bid by quoting a single spread for both bonds, but against different benchmarks: U.S. Treasuries of May 2008 for the seven-year bonds, and those of August 2027 for the twenty-year bonds. The Ministry of Finance announced a minimum spread of 837.5 basis points. Finally, offers for new money bonds up to $\$ 500$ million under the same rules would also be entertained.

The bid results were announced on July 20, 1998. At the maximum spread of 940 basis points chosen by the ministry, the total face value of Eurobonds to be issued was $\$ 6.4$ billion, of which $\$ 0.5$ billion consisted of new money bonds and $\$ 5.9$ billion pertained to the GKO swap. The latter were to be issued in equal tranches of seven-year ( 8.75 percent coupon) and twenty-year (11 percent coupon) bonds and were priced to yield 940 basis points over their respective Treasury benchmarks, for a yield to maturity (internal rate of return) of 14.9 percent for the seven-year and 15.2 percent for the twenty-year bonds. In other words, the bonds were sold at a steep discount, at a price of 73.8 percent, so that the proceeds 
available for GKO redemptions amounted to just $\$ 4.4$ billion (73.8 percent of $\$ 5.9$ billion).

Conceptually, the swap was equivalent to issuing Eurobonds for dollars and using the dollar proceeds to retire GKOs. It was based on the following intuitive notions: that if the exchange rate is fixed, low nominal interest rate debt is preferable; and that lengthening the maturity would help at a time of high rollover risk. This assumed, first, that an interest arbitrage opportunity existed that the market had ignored, and second, that the government could unilaterally choose maturities even at a time of high default risk. In the event, there was not much demand for the Eurobonds: even at the maximum acceptable bid spread of 940 basis points, the amount raised was less than 15 percent of the $\$ 32.7$ billion in GKOs and OFZs maturing over the last seven months of 1998. This indicated that the bulk of GKO holders preferred to hold on to their one- to four-month paper yielding 50 percent or more rather than swap it for Eurobonds, which would mean continuing their long-term exposure, although the risk of devaluation would be eliminated. This behavior supports the view that GKO holders believed a devaluation would not occur until November 15 because of the Moscow banks' exposures. Another possible motivation was that the large financing package would enable easy exit.

However, the situation started unraveling soon after the swap was completed. Table 10 shows the impact of the debt restructuring effort, which began with the June Eurobonds, on the market yields of GKOs and the 2001 and 2007 Eurobonds. The table reports yields on these instruments for the last trading day before, the day of, and the first trading day after several key events. Essentially, GKO yields fell with the two June Eurobond issues, thanks to a temporary improvement in liquidity, but then resumed rising. Eurobond yields meanwhile rose continuously. With the July 13 announcement of the package, although GKO yields halved, bond yields fell much less, and both resumed their rise after the completion of the GKO-Eurobond swap on July 24. As noted above, both devaluation risk and default risk jumped sharply after the swap was completed.

The jump in default risk can be explained by two factors: first, the swap did not reduce total debt, and second, it may not have improved public debt dynamics. Recalling equation 1, with the primary deficit, growth, and existing debt fixed in the short run, such a swap would improve public debt 
Table 10. GKO and Eurobond Yields on Selected Dates, June-August 1998

Percent a year

\begin{tabular}{llccc}
\hline Date & Event & $\begin{array}{c}\text { One-year } \\
\text { GKO }\end{array}$ & $\begin{array}{c}\text { Three-year } \\
\text { Eurobond }\end{array}$ & $\begin{array}{c}\text { Ten-year } \\
\text { Eurobond }\end{array}$ \\
\hline June 3 & & 56.7 & 11.3 & 11.7 \\
June 4 & \$1.25 billion in Eurobonds issued & 46.2 & 11.4 & 11.8 \\
June 5 & & 47.4 & 11.3 & 11.7 \\
June 17 & & & & \\
June 18 & \$2.50 billion in Eurobonds issued & 54.4 & 12.1 & 12.2 \\
June 19 & & 56.1 & 12.3 & 12.6 \\
July 10 & & & & 12.9 \\
July 13 & Financing package and GKO- & 107.1 & 16.1 & 15.1 \\
July 14 & Eurobond swap announced & 58.2 & 14.0 & 14.2 \\
& & & & 14.6 \\
July 17 & & 52.4 & 13.6 & 14.6 \\
July 20 & Financing package approved & 51.6 & 13.3 & 14.6 \\
July 21 & by IMF, \$4.8 billion released, & 48.4 & 12.7 & 14.0 \\
& swap terms announced & & & \\
July 23 & & & & \\
July 24 & GKO-Eurobond swap completed & 64.2 & 13.7 & 15.1 \\
July 27 & & 75.1 & 15.5 & 15.5 \\
August 14 & Eve of crisis (Friday) & 14.7 & 17.3 \\
\hline
\end{tabular}

Source: Brunswick UBS Warburg, Moscow.

a. Shows one trading day preceding and one trading day following the event.

dynamics only if it lowered $r$. Recalling that $r=w r_{d}+(1-w)\left(r_{f}-\rho\right)$, and using $\Delta r=d r / d w \times \Delta w$, we get

$$
\Delta r=\left(r_{d}-r_{f}+\rho\right) \Delta w+w \Delta r_{d}+(1-w)\left(\Delta r_{f}-\Delta \rho\right)
$$

The idea that the swap would help was based on the first term on the righthand side of equation 4 , namely, the real interest differential, $r_{d}-r_{f}+\rho .^{53}$ We illustrate the importance of looking at all three terms on the righthand side with a simple numerical example based on numbers prevailing

53. Comparing equations 3 and 4 , and noting that, with a constant ruble-dollar real exchange rate target, ex ante, $\rho=0$, and that the nominal devaluation target is therefore given by the expected Russian-U.S. inflation differential, this expression is just the 
just before the June 18 Eurobond was issued. At the time, GKO yields were around 50 percent; the inflation target was 8 percent; the real exchange rate was targeted to be kept flat; $r_{f}$ based on the June 4 Eurobond was roughly 10.3 percent (total cost, including estimated commissions, was 12.5 percent versus U.S. inflation of 2 percent); $w$ was about 30 percent; and Russia's total public debt was about $\$ 180$ billion. ${ }^{54} \mathrm{~A}$ hypothetical $\$ 20$ billion swap out of GKOs into Eurobonds would give $\Delta w$ of about -0.11 . It is assumed conservatively that this would raise $r_{f}$ by 2 percentage points, as Russia would effectively exhaust its access to the Eurobond market with a swap of this size. We also assume that a temporary drop in $r_{d}$ would result from the swap; it would be only temporary because the primary deficit still needed to be financed, and the volume of maturing debt far exceeded $\$ 20$ billion, as shown in table 6 . Russia would have to return to the GKO market to finance this. To summarize, $r_{d}=0.39$; $r_{f}=0.103 ; \Delta w=-0.11 ; \Delta r_{d}=-0.05$.

Using equation 4 , it can be calculated that if $\Delta \rho$ was less than $-0.047-$ that is, if the ruble depreciated in real terms by 4.7 percent or more, $r$ would actually go up, and all the benefits from the swap would be nullified. This was well within the bounds of possibility. Forecasts for the trade surplus at the time were a maximum of $\$ 15$ billion; a $\$ 20$ billion increase in foreign debt at 12.5 percent interest would mean an increase in interest payments of $\$ 2.5$ billion a year, or 17 percent of this projected surplus. This example shows that the anticipated savings from a debt swap may be overstated if due consideration is not given to the impact on foreign interest rates and to the expected depreciation rate in circumstances where default risk and the share of foreign debt are high. As shown in table 8, the market's expectation of devaluation risk jumped by 12.6 percentage points, and default risk by 2.2 percentage points, between the announcement of the swap auction results on July 20 and its settlement on July 24 .

These jumps did not occur without warning. As already noted, even though GKO yields halved after the package was announced on July 13,

devaluation risk premium. That is, it is that portion of the nominal ruble-dollar interest differential not explained by the targeted rate of nominal devaluation. The swap in effect assumed that there was no justification for the devaluation risk premium, or in other words that the ruble was not going to depreciate against the dollar by more than its target rate.

54. As noted in the introduction, there was a substantial increase in foreign debt during 1998. 
they remained far above the crisis levels of mid-May. Further, in announcing the swap, the Ministry of Finance also said it would no longer issue debt of less than a year's maturity. On July 22 it issued three-year OFZs, but the proceeds raised were only 36 percent of the redemption amount of maturing paper, for a shortfall of $\$ 0.9$ billion. Both events indicated market skepticism about the package.

Nevertheless, initial reaction to the swap announcement had been positive. It was greeted as "The Great Rouble/Dollar Debt Swap" and "as the most positive aspect of the program." ${ }^{55}$ According to market participants, the following factors played a role as the situation unraveled. ${ }^{56}$ Some felt they could take advantage of the price premium being offered on near-term GKOs to switch into Eurobonds, then immediately sell the Eurobonds and move back into GKOs. Others found that when they wished to sell the Eurobonds they had acquired in the swap to outside investors (hedge funds and big pension funds) as a way of exiting the Russian debt market, there was no appetite for the paper. The swap was soon followed by a large liquidation of dollar-denominated government paper by a major, cashstrapped Russian bank trying to meet margin calls. ${ }^{57}$ The additional paper depressed the prices of Russian sovereign debt, leading to accelerated margin calls on repos entered into by Russian banks. This coincided with a large volume of syndicated loans falling due in August, a peak month for loan rollovers, which many banks had to repay in part or in full. ${ }^{58}$ Margin calls and loan repayments meant a forced sale of GKOs to raise liquidity. This implied that had the swap been bigger in size, the effects would have been even worse. Finally, the CBR was losing reserves at a rate of $\$ 1$ billion a week. As GKOs were perceived to be the most risky asset, subject to

55. MFK Renaissance, “The Great Rouble/Dollar Debt Swap,” Fixed Income Update, July 14, 1998; Brunswick Warburg, "Does IMF Package Mark the End of the Ruble Crisis?" July 14,1998 . However, the risk of unloading a large volume of Russian dollar debt onto an uneasy market, adding to the pressure from sales by cash-strapped Russian banks, was noted in the MFK Renaissance article.

56. Conversations with investment bank analysts by Brian Pinto in August and September 1998 and in February and March 2001.

57. The bank was identified as SBS-Agro. See also Andrew Higgins, "Insufficient Funds: How a Russian Banker Outfoxed Creditors to Rebuild an Empire-Alexander Smolensky's Return Lays Bare the Weakness Still Pervading the System," Wall Street Journal, October 4, 2000, p. A1.

58. Total bank debt maturing in 1998 was estimated at $\$ 2.1$ billion, of which $\$ 0.6$ billion would come due in the first half and $\$ 1.5$ billion in the second, with a peak in August at $\$ 0.5$ billion (Reuters, July 30, 1998). 
both default and devaluation risk, exit from these obligations intensified, leading to the meltdown.

Cumulatively, Russian-era external debt had increased by close to $\$ 16$ billion between June 1 and July 24, 1998, compared with a debt stock of $\$ 36$ billion at the start of the year. This increase in indebtedness, combined with the exposures of Russian banks, was what triggered the August crisis.

\section{Conclusions and Lessons Learned}

Large fiscal deficits locked in by the nonpayments problem, real appreciation caused by the disinflation strategy, and poor growth prospects all interacted to place Russia's public debt dynamics on an unsustainable footing. This eventually precipitated a crisis along the lines of the Krugman-Flood-Garber and Sargent-Wallace models.

Given the fundamentals, the twin financial innovations accompanying the promise of fiscal and structural reforms-the liquidity injection prior to the crisis and the public debt restructuring through the GKO-Eurobond swap-did not work as anticipated. The injection of reserves as part of the package improved liquidity but may have worsened the short-term public debt dynamics. It increased the public debt at a time when default risk was high, and it created a senior claim on resources at a point when time-consuming fiscal reforms would have been needed to meet the additional debt service requirements. The impact of the GKO-Eurobond swap was less than anticipated because of the upward-sloping marginal cost of foreign borrowing faced by the Russian government in an environment where default risk was already high. At the same time, this swap may have made the banks even more vulnerable to margin calls on loans and repos collateralized by Russian government dollar-denominated paper, forcing them to liquidate their assets, whose market value had already been substantially reduced by rising devaluation and default risk premiums. With GKOs considered the most risky asset, exit from them intensified, bringing the crisis forward in time.

With the fundamentals obviously weak, why did the market permit so much Russian debt to be built up in the first place? Four possible reasons come to mind. First, the large real appreciation of the ruble obscured the true underlying debt dynamics. Second, Russia was widely expected to 
resume growing by 1996 and achieve sustainable growth by 1997, creating the hope that the country would grow out of any debt trap. Third, there may have been a genuine belief that a devaluation would be bad for Russia. ${ }^{59}$ This was partly based on the view that stabilization would lead to a resumption of growth. ${ }^{60}$ In this view a devaluation and a rise in inflation would have reversed what were seen as hard-won stabilization gains. Fourth, moral hazard might have played a role. Portfolio investors might have been anticipating a large bailout that would at least postpone a crisis and keep their one-way bet alive for a few more lucrative months. ${ }^{61}$ Exiting the GKO market was believed to require only a couple of days by the spring of 1998. A domestic political factor pushing in this direction was the off-balance-sheet exposure of the large, well-connected Russian banks to currency forward contracts, which were known to have maturity dates bunching in mid-September, mid-October, and mid-November 1998. Therefore, it might have been reasoned, any devaluation would be postponed until at least after mid-November to protect the banks.

Based on the analysis presented here, it is very likely that the moral hazard explanation dominated after May 15, 1998, when market signals on devaluation and default risk took a decided turn for the worse, yet investors were willing to increase their exposure to Russia. The insurance argument in the form of an international financing package probably played an increasingly important role: ${ }^{62}$ recall the estimates in box 2 of how large private sector analysts thought a financing package would have to be. As it turned out, Russia was offered a much smaller financing package ( $\$ 22.6$ billion, or 5.8 percent of its GDP) than Indonesia ( $\$ 40$ billion, 18.1 percent of GDP), Mexico ( $\$ 47$ billion, 13.5 percent of GDP), or Korea ( $\$ 57$ billion, 11.7 percent of GDP) ${ }^{63}$ Moreover, only about a quarter of Russia's financing package was actually disbursed, minimizing moral hazard.

59. This was argued, for example, by Åslund ("Don’t Devalue Ruble”) and Wolf ("Russian Knife-Edge").

60. Fischer, Sahay, and Végh (1996).

61. Commenting on the June 18 Eurobond issue, Lawrence Mutkin ("Actually, Russia Can Fail," Market Commentary, Tokai Bank Europe, June 19, 1998) noted: "Readers should recognize that this issue was sold . . essentially because investors believe that Russia will not be allowed to fail, rather than because its fundamentals are encouraging."

62. Dooley (1998).

63. Calvo and Reinhart (1999, table 3). 
At the same time, Russia managed to "bail in" both private investors in GKOs and OFZs and holders of Soviet-era debt under the auspices of the London and Paris Clubs after the crisis. It very successfully negotiated agreements with GKO and OFZ holders despite initial criticism that its offer was one-sided and discriminated against foreign investors. The face value of domestic debt covered by the August 17, 1998, restructuring amounted to some $\$ 44$ billion at the immediate precrisis exchange rate, of which 30 percent was held by nonresidents, who are estimated to have eventually received 5 cents on the dollar. The vast majority of creditors (over 99 percent by value) eventually signed on. In retrospect, the acquiescence of GKO and OFZ holders is not surprising given the high levels of default risk priced into these instruments. ${ }^{64}$ London Club creditors ended with a loss estimated at 50 percent in present value terms. Paris Club creditors rescheduled most debt service payments due in 1999 and 2000.

Although some of its features are peculiar to the dynamics of transition countries or to the Russian situation specifically, Russia's meltdown does offer some general lessons for countries with fixed exchange rate pegs. First, it is extremely difficult to design an international package to deal with both wavering confidence and weak fundamentals at the same time, because the interaction between high default risk and high devaluation risk can be complex. A debt-based liquidity injection that aims to boost confidence could worsen public debt dynamics while offering heavily exposed investors a convenient selling opportunity. In this sense the financing portion of the package could actually trigger a crisis if the market is sufficiently skeptical about the implementation of fiscal and structural reforms. This argument is even stronger if the liquidity injection involves debt that is perceived to be senior to the existing claims of private creditors. Similarly, swaps between short-term, high-coupon domestic currency debt and long-term, low-coupon foreign currency debt may not work, as the interest arbitrage may be illusory, and the government may not be able to unilaterally select maturities at a time of high default risk. There might be other unintended effects. The Russian banks were exposed to margin calls on repos collateralized with dollar-denominated government paper, and the swap increased the outstanding volume of that paper, depressing its price and leading to the forced sale of GKOs to raise cash for these margin calls, setting off a downward spiral.

64. The devaluation alone accounted for over 70 percent of the loss. 
In these circumstances, a judgment must be made about the probability that portfolio investors will force a devaluation by exiting the domestic securities market. For example, had it been judged in the Russian case that a defense was going to be unsuccessful because of economic fundamentals and market signals, an alternative strategy would have been to float the currency while restructuring agreements were sought with holders of GKOs and external debt in the context of a program to address fiscal and structural reforms. In either case-that of defending the currency unsuccessfully or that of a preemptive float - there would have been a common set of economic costs. The banks would still have failed, inflation would still have gone up, and a recession would still have occurred. There would also very likely have been some disruption in market access, creating an incentive to address the fiscal imbalance, and the devaluation would have increased domestic output and decreased nonpayments-much as actually happened after August 17. ${ }^{65}$ The main virtue of anticipating the crisis is that it would have avoided incurring incremental foreign debt in an unsuccessful defense. ${ }^{66}$

Another judgment pertains to the need for an early real exchange rate adjustment as an integral part of fixing the fundamentals. Even though the current account was roughly balanced in the Russian case, growth performance and prospects were weak, and the precrisis real appreciation had not been accompanied by rising productivity in the enterprise sector. Further, with chronic fiscal imbalances, the biggest threat to the exchange rate may have been the risk that the deficit and the public debt would ultimately have to be monetized, and this is what the market appeared to be signaling by early 1998. In fact, by then the Sargent-Wallace conditions were satisfied: real interest rates exceeded the growth rate; the government was financing the deficit by issuing debt and rolling it over to keep current inflation low; and the debt-GDP ratio appeared to be reaching an upper bound, as indicated by a high and rising default risk premium. If these conditions are met in a situation where growth prospects are deteriorating, the chances diminish that the government will be able to raise

65. Ahrend (1999); IMF (2000a); Pinto, Drebentsov, and Morozov (2000b). The potency of the real exchange rate stimulus became obvious only after the crisis, as indicated in output developments during 1999 and 2000.

66. In the Krugman-Flood-Garber model, the postattack inflation rate increases with the size of the fiscal deficit, which in turn increases with interest payments on government debt. 
taxes and fix the fundamentals. A real exchange rate correction may then become inevitable, partly to reduce the burden of domestic debt, and partly to give the enterprise sector some relief.

Second, a bail-in or the imposition of losses on private investors can be valuable in improving public debt dynamics; in practice, however, it may be difficult to include in a reform package ex ante, for several reasons. First, when default risk and devaluation risk are already high, the loss to creditors needed to restore fiscal balance may be so large that they head for the exits anyway. Second, given the different classes of debt, each with its own risk-return profile, apportioning the loss across different types of creditors may be difficult to accomplish in a short period. Third, if the imposition of losses has as its goal the preservation of market access, this could itself dilute the incentives for correcting the fiscal imbalance. ${ }^{67}$ Thus a private investor haircut may best be undertaken in a crisis atmosphere such as that which followed the August 17 devaluation in Russia.

Third, it is important to understand the key market players, their payoffs under alternative scenarios, and their trading and likely exit strategies. It is unlikely that large, unexploited arbitrages exist for exploitation by financial engineering. The GKO-Eurobond swap provides a telling illustration. On July 24, 1998, a little less than $\$ 3$ billion worth of twenty-year bonds were issued at a price of 73.858 with a coupon of 11 percent, for an annual yield to maturity of 15.2 percent in dollar terms, in connection with the swap. ${ }^{68}$ If one takes the exchange rate as 24.2 rubles to the dollar by the time of the first coupon payment (the actual exchange rate in July 1999) and assumes a nominal devaluation of 8 percent a year thereafter up to 2008 and 5 percent after that to maturity (a plausible scenario), the internal rate of return on the ruble-equivalent cash flow stream is 65.6 percent

67. Eichengreen and Ruehl (2000) discuss the cases of Ecuador, Pakistan, Romania, and Ukraine in the wake of the East Asian and Russian crises. They identify avoiding a “... costly, extended interruption to market access" as a primary goal, and they argue for the same reason that the IMF and the World Bank are not credible when they seek to bail in the private sector as part of a new money package. The Russian case appears to contradict these arguments. As noted, only a quarter of the funds earmarked by the IMF and the World Bank as part of the package was eventually disbursed ( $\$ 5.1$ billion out of $\$ 21.1$ billion). Russia was allowed to fail, private investors did take a big hit, and the disruption in market access stimulated reform.

68. Also issued on July 24 were slightly less than $\$ 3.0$ billion in 8 percent coupon bonds at a price of 73.8 and a seven-year maturity, and new money bonds of $\$ 0.5$ billion on the same terms as the twenty-year bonds, for a total of $\$ 6.44$ billion. 
per year for twenty years. This compares with a one-year GKO yield of 66 percent on July 24, the date the swap was settled. The general lesson is that the market was pricing both devaluation risk and default risk in a consistent fashion. In such circumstances, efforts to reduce devaluation risk by enhancing liquidity may not help if, by construction, this involves a simultaneous and matching increase in debt.

Fourth, there must be well-founded confidence that the package is indeed moving the economy to a "good" equilibrium through a transition characterized by a fixed exchange rate band and market access while reforms are bring implemented. If, instead, this is a low-probability event because of a basic policy inconsistency, then a defense of the currency only adds to the costs. In the case of Russia, the real appreciation of the ruble suppressed growth, and this, coupled with an inability to remedy fiscal deficits because of the nonpayments problem, precluded the "good" equilibrium from being realized. The very crisis that the package sought to avert contained within it the foundations for future recovery. It brought about the suspension of access to market borrowing for the government, which is forcing fiscal reform and the dismantling of the nonpayments system. It also brought about a real depreciation, which is helping domestic industry, and a reduction in the real value of public domestic debt through higher inflation.

To conclude, the fiscal reforms required to reduce borrowing needs and the structural reforms required to promote growth typically take time to implement and yield visible results. Although incumbent policymakers would obviously prefer to buy this time without any serious economic dislocation, once the country has entered serious default risk territory the market may simply be "unforgiving," to use Guillermo Calvo's term. ${ }^{69}$ In such a case, designing a package based on deliberately changing the exchange rate, reaching an agreement with creditors, and simultaneously implementing fundamental reforms is by definition less costly than waiting for the market to force the same set of actions. 
APPENDIX

Chronology of Key Events Surrounding the Russian Meltdown

Date Event

End of October 1997 The IMF mission to Russia decides not to recommend completion of the sixth quarterly review under its Extended Fund Facility (EFF) program loan. This action coincides with the first bout of foreign exchange market instability as contagion from the Asian crisis hits.

November 10

The CBR announces that, beginning January 1998, the ruble will be targeted at a central rate of 6.2 to the dollar within a \pm 15 percent band.

November 11

After losing reserves, the CBR raises the refinance rate from 21 percent to 28 percent. Reserves fall by $\$ 6.1$ billion for the month as a whole.

December 2-12

The IMF mission decides to recommend completion of the sixth quarterly review in view of the crisis situation and the willingness of the Russian government to take much tougher measures, as laid out in the Fiscal Action Plan, to raise revenue and control expenditure.

December 18

The World Bank board of directors approves the second Structural Adjustment Loan (\$800 million) and the second Sectoral Adjustment Loan to the government to support reforms in the coal-mining industry (\$800 million).

January 8, 1998

The IMF board of directors approves completion of the sixth quarterly review; the corresponding $\$ 700$ million tranche of its EFF loan is released.

Late January 1998

A second bout of foreign exchange market instability occurs; portfolio investors complain of policy drift as concerns mount over Russian fundamentals and policy credibility. 
Early to mid-February President Boris Yeltsin makes tough pronouncements on protecting minority shareholder rights, renouncing tax offsets, and creating a good investment climate for foreign direct investment, including through tax reform and passage of the 1998 budget. He uses his February 17 State of the Nation address to reinforce these positive signals.

March 4

The Duma passes the 1998 budget with the Ministry of Finance's tough expenditure control mechanisms intact.

March 23

Prime Minister Viktor Chernomyrdin is dismissed.

April 24

Mid-May

May 23

End of May Prime Minister Sergei Kirienko is confirmed on the third vote after a protracted delay.

The Indonesian political and financial crisis erupts, igniting a third and eventually conclusive episode of foreign exchange market instability in Russia.

The IMF mission leaves without finalizing the 1998 EFF program.

June 4

Financial volatility intensifies.

Russia issues five-year dollar Eurobonds for $\$ 1.25$ billion at face value, at a spread of 650 basis points over U.S. Treasuries.

June 18

Russia issues a thirty-year dollar Eurobond for $\$ 2.5$ billion at face value with a put-at-par option after ten years, at a spread of 753 basis points.

June 23

Negotiations begin on a new IMF-World BankGovernment of Japan enhanced package.

June 25

Meanwhile, the IMF board approves the 1998 EFF program, under discussion since early 1998; a $\$ 670$ million tranche is released.

July 13

An emergency $\$ 22.6$ billion international package is announced. GKO yields halve. The GKO-Eurobond swap is also announced; bids are invited with a deadline of July 17. 
July 20

July 24

August 6

August 17

August 23-24

August 28

September 2

September 3

September 11

Mid-September
The IMF board approves the emergency package, but the size of the first disbursement is reduced from $\$ 5.6$ billion to $\$ 4.8$ billion as the Duma stalls on key expenditure control and tax measures. Results of bids under the GKO-Eurobond swap are announced.

GKO yields return to levels of mid-June, coinciding with completion of the GKO-Eurobond swap. Including new money of $\$ 0.5$ billion, the total face value of bonds issued is $\$ 6.4$ billion, at a spread of 940 basis points over Treasuries.

The World Bank's board of directors approves the third Structural Adjustment Loan; $\$ 0.3$ billion out of $\$ 1.5$ billion is disbursed, in keeping with the Bank's backloading strategy.

Week ending August 14 The CBR loses $\$ 1.7$ billion in reserves as portfolio investors exit, bringing the total loss from July 10 to August 14 to $\$ 10.5$ billion. The CBR also bails out SBS-Agro with a $\$ 100$ million loan. Meltdown week.

Devaluation, debt restructuring, and a partial payments moratorium are announced.

Prime Minister Kirienko is dismissed.

The CBR places SBS-Agro under temporary administration; this move is overturned by a court ruling on August 31.

The ruble is floated after $\$ 2.8$ billion in reserves is lost between August 17 and September 2.

The CBR places Inkombank under temporary administration; this action, too, is overturned in court on September 7.

Prime Minister Yevgeny Primakov is confirmed.

Accusations of manipulation are made as the CBR exchange rate rises from a low of 20.8 rubles to the dollar on September 9 to 8.67 on September 15, the maturity date for a significant batch of currency forward contracts. 
October 6

October 28

October 30

November 4
A segmented foreign exchange market is introduced.

First Deputy Prime Minister Yuri Maslyukov gives the IMF mission a copy of a draft economic emergency plan.

The IMF mission leaves, with large unresolved differences on the budget as well as on the action plan to address the crisis.

Maslyukov admits that Russia will not be able to meet its sovereign debt payments. 


\section{Comments and Discussion}

Lawrence H. Summers: Just as it is useful in medicine to do post mortems and autopsies, so in economic and financial policy it is useful to conduct reviews of episodes in which things do not work out in ways that are completely satisfactory to any of the participants. So it is with the Russian financial crisis and the emergency international operation undertaken to resolve it. I must confess, however, that in listening to the oral presentation of this review of the episode, I was reminded of my first several sessions as a participant on this panel. Back then I was always surprised that people like Arthur Okun and James Duesenberry, who were much more experienced and knowledgeable than I, seemed so much in doubt about some issues to which I was sure I knew the answers. There is an air of breathless revelation to the analysis in this paper, as if the authors believed that those involved in the design of the international rescue package were unaware of the fiscal situation in Russia, unaware of interest parity conditions, unaware of first-generation crisis models, unaware of Sargent and Wallace's unpleasant arithmetic, and unaware of the need to restore confidence by getting the fundamentals right. To my knowledge, which is that of a close participant, there was general awareness of all these issues at the time.

Indeed, I found the paper somewhat misleading in not emphasizing what the IMF regarded as a central part of its strategy, namely, imposing conditions on Russia with respect to its fiscal policy. These conditions were intended to have the effect of bringing the budget more closely into balance, and so precisely to address the fiscal fundamentals. The conditions, and the effort to apply them, were central to the timing of disbursements under the program, and central to its design. And at least on the 
interpretations that the IMF has offered in the wake of the crisis, the failure of the Russians to meet those conditions was central to the program's failure.

One can debate whether those conditions were well designed. One can debate whether, if those conditions had been met, it would have made any difference in the end. But to portray the program as essentially a financial engineering strategy that hoped to restore confidence while taking the Russian fiscal situation as given is not consistent with my recollection of the program at the time. In addition, one can debate whether, in fact, the effort to shave a couple of tenths of a percent of GNP off the fiscal deficit did more to reduce confidence than the fiscal improvement itself would have increased it, and whether the fiscal component of the program was, therefore, well managed. But to write fifty pages about the program while ignoring a main feature of its policy content does not, in my view, do the program justice.

To be sure, the premise of the program was that, in a very uncertain environment, there was the prospect-not the certainty, not even necessarily the high likelihood - that properly provided financial support, in conjunction with policy conditions, could restore confidence and bring about a material improvement in the Russian situation. It was self-evident to all involved that the steps being taken would be of value only in the context of a successful effort to restore confidence. If confidence were not restored, it would prove to have been unwise to have lent money and built up debt, and to have allowed the existing debt to have its maturity extended and be redenominated in dollars.

There can be no mistake that the program did fail in more or less the way that its authors would have predicted had they been asked the question, "If this program doesn't succeed, what will happen?" The failure scenario played out, more or less, in the way that was expected. Therefore it seems to me that the right questions to ask about this episode are threefold: First, was the strategy a plausible one, or was it just a misguided, confused attempt from the start? Second, given the strategic objective of maintaining confidence and working within the existing regime, could the program have been carried out in a more effective way? Third, what are the broader lessons to be learned?

On the question of whether the strategy was plausible, three points should be noted. The first is that, at the time the program was initiated, the ratio of debt to GNP in Russia would have met the Maastricht criteria 
for entry into European monetary union. Indeed, it was lower than the ratio of debt to GNP in the average G-7 country. The primary fiscal deficit was less than the average primary deficit of the United States over the preceding decade. The disastrous debt dynamics derived from the 27 percent marginal real interest rate, which in turn derived from the combination of interest parity considerations and the expectation that the exchange rate would not hold. So the notion was that, if confidence were restored-if there were an expectation that the exchange rate would hold and that interest rates would fall to a reasonable level-there was then the prospect that the fiscal arithmetic was ultimately sustainable. Was that a highly likely scenario? It is difficult to be certain. But it is important to remember that the primary deficit and the debt-to-GNP ratio were in a relatively normal range.

The second point - and a consideration that drove the choice of a program, at least as I recall —was that there was no alternative strategy that the Russian authorities were prepared to pursue. Now, one can argue that, if a country declines to pursue strategies recommended by the international community, it should not get any support from the international community. However, those who frequently criticize the international financial institutions for their high-handedness and imperiousness in dealings with democratic countries need to contemplate that there was no other strategy that the Russian authorities were willing to consider in the early summer of 1998.

Third, there was the plausible argument, adduced with great force at the time and in some ways justified by events, that a devaluation and its aftermath would represent the shattering of the Russian reform effort. It was feared that the collapse of the ruble would lead to quite substantial backtracking on reforms across a broad front, not to mention adverse foreign policy consequences from the perception that the West was pulling away from Russia.

Was it the judgment of those involved that the strategy chosen was guaranteed of success? No. Was it the judgment of those involved that it had a high likelihood of success? No. Was it their judgment that it had a reasonable chance of success? Yes. Was the judgment that a reasonable chance of success, given the stakes involved, constituted a chance worth taking? Yes, that was the judgment that was made.

Given that this is how the decision was framed, it seems to me that informed critiques of the decisionmaking process must do one of two 
things. Either they must argue that it was not worth taking a reasonable, but by no means certain, chance given the stakes involved in Russia. Or they must argue that it was wrong to suppose that the program had even a reasonable chance of success. Those arguing the latter need to account for the behavior of the rather large number of prominent financial institutions that, in June and July of 1998, were prepared to invest very substantial amounts of money in Russian paper.

A doctrine that former Treasury Secretary Robert Rubin has stated with great frequency is that it is naïve to judge decisions only by outcomes. One can make wrong decisions and have things turn out right, or one can make ex ante right decisions and have bad outcomes nonetheless. An analysis of this episode should recognize that point more explicitly than is done in this paper.

Turning to the second question, given the decision to support Russia in, broadly speaking, the policy regime then in place, would different tactics have offered a greater prospect of success? Was there an alternative model that would have worked better? Here it seems to me there are four questions that one can ask. The first concerns the handling of Russia's fiscal policy. The Fund felt very strongly that it was important to have meaningful signs of fiscal progress that materially reduced the deficit, and to have those not just taken by executive action, but pass the Duma. True, that did have the effect of giving the Duma enormous leverage vis-à-vis the Russian administration, since the Duma could then control the possibility of IMF tranche releases. On the other hand, it had the benefit of actually forcing real fiscal action.

It is, I believe, debatable whether the Fund should have insisted on more fiscal action, addressing the debt dynamics, or insisted on less, because the imperative of the situation was restoring confidence. One could argue that giving the Duma a knife to hold at the throat of the Russian administration undermined rather than bolstered confidence and added more to the deficit through higher real interest rates than it took away through any policy leverage. The fact that one can make either argument with a certain plausibility suggests that the Fund may well have found an optimum in between those two choices, but that remains an open question. At the time, I subscribed somewhat to the second view, but with the benefit of hindsight, I am not sure that I was right.

Second, was the swap of GKOs for long-term dollar-denominated bonds well conceived? In the context of the overall failure of the rescue, 
the swap was not very successful. Few investors were prepared to exchange short-term Russian obligations for long-term Russian bonds even at attractive interest rates. I cannot quite tell from the authors' presentation, however, whether they think the problem with the swap was that too many people took it, and therefore the creation of senior debt made the situation worse, or that not enough people took it, and therefore the swap failed to create more liquidity. I believed at the time, and still believe, that the effort to replace short-term with long-term debt, to reduce immediate cash needs in a situation where one is facing a run, was well conceived. In the context of a successful restoration of confidence, it could easily have made a substantial contribution to improving the situation. The right question to ask, in my view, concerns the validity of the general doctrine that the authors enunciate, namely, that seeking to extend debt through lower-yielding hard currency debt is always a misbegotten strategy. I would be surprised if that were the case.

The third tactical question that can be asked is, Should the emergency financing package have been larger or smaller? One can argue-and the authors hint at this in one or two places - that there is a kind of Powell Doctrine in financial rescues: if resources are insufficient to redeem all the GKOs, or at least a large fraction, then providing more limited resources only invites the rush to the door. One can counter that, in a very uncertain environment, one should not put too much money at risk. And here, too, an interior solution was found in the Russian case. My guess, in retrospect, is that if the attempt was going to be made, it should have been made a little bit more confidently, on a somewhat greater scale. But that, too, is a question that seems reasonable to debate.

The fourth question about the program, and the one that virtually everyone who is not a macroeconomist asks first, is the following. What is the point of fretting over debt ratios and sustainability and debt dynamics when the whole country is completely corrupt? How can you ever hope to restore confidence in such a situation? Whether some greater attempt to address the corruption issue was possible in some relevant time frame and should have been a larger part of the program is, it seems to me, another question that reasonable people can debate, and that serious analysis should engage.

Let me turn, finally, to three broader lessons from this episode. The first relates to the choice of exchange rate regime. We have witnessed time and again the dangers of pegged but not institutionalized exchange rates. 
The single common element in Mexico in 1994 and in Thailand, Korea, Indonesia, Russia, and Brazil in 1997 and 1998 was an exchange rate that was pegged without sufficient institutionalization of the measures necessary to make the peg stick. This is a constant temptation to policymakers. And as the considerations I have mentioned in explaining some of the motivations for the Russian program indicate, once a pegged regime is in place, it is very difficult not to defend it.

The problem is not unlike that of the Coast Guard or the National Park Service. It is all very well to tell people that they should not climb mountains at night or take their boats out in stormy weather. But if people choose to do these risky things, allowing them to die in the name of preventing moral hazard is not a plausible option. One can try to charge people for rescuing them, or one can try to devise rules of various kinds to stop people from doing those things.

It seems to me that, in the interest of the international community, which pays for supporting bailouts like that of Russia, the Fund needs to militate more strongly against pegged exchange rate regimes that lack proper institutionalization. And it should do so on an ex ante basis, because it is very difficult to do ex post. That position is accepted with a certain amount of lip service by the Fund board and Fund management, but historically it has not been put into practice, as evidenced by the recent crisis in Turkey, which of course happened after Mexico, Thailand, Russia, and the rest. My hope is that this position, which is perhaps the only one on which 90 percent of economists who have studied these matters agree, will come to find wider application in the years ahead.

The second broad lesson is that macroeconomics cannot be divorced from the broader structural challenges of reform. Despite rather extensive analysis after the fact of the IMF's rather substantial efforts in Russia over the last seven years, the ex post analysis of the World Bank's effortsor nonefforts-in Russia to address structural challenges has been rather more attenuated. It would be useful to think through whether the amount of money that has been moved is in due proportion to the amount of genuine progress made in support of structural reform in Russia.

The third and final lesson concerns whether international financial institutions are the appropriate vehicle for efforts like that in Russia, or whether they are more appropriately done bilaterally. There is an argument that, given the broad political stakes involved, such efforts should be undertaken outside of the international financial institutions, with direct political sup- 
port. But I believe a stronger argument is that these efforts are very difficult for one country or group of countries to take explicit political responsibility for, that doing them well requires substantial technical expertise, and that they are therefore best divorced, to some degree, from foreign policy concerns and instead done through international financial institutions.

Let me conclude by thanking the authors for what I think is a serious attempt to raise real issues of understanding about what took place in Russia. Reviews of this kind are timely and will initiate a useful dialogue, which will lead, over time, to improvements in the policy process.

John Williamson ${ }^{1}$ : This paper contains a vivid and thoughtful account of the events that led up to the meltdown of the Russian economic program in August and September 1998. The authors ask the right questions about what underlay the crisis, and I find their answers persuasive.

I have not followed the Russian economy in any detail since I was there a couple of times for brief periods when the transition was just getting under way. At that time I did not feel that I fully grasped what was going on, nor, I confess, was I convinced that most of my colleagues in the advice-dispensing business had a much more profound understanding than I did. Sadly, these doubts came flooding back as I read the advice that Western economic institutions were dispensing to the Russian government before the crisis.

The paper attributes the crisis to unsustainable debt dynamics. Russia had a large fiscal deficit, principally because the government was tolerating underpayments of tax both by the manufacturing sector and by energyproducing enterprises, in the latter case as a quid pro quo for extending soft budget constraints to their manufacturing clients. These subsidies were intended to prevent manufacturing from being completely eviscerated by the real overvaluation of the ruble and the high real interest rates that had resulted from the 1995 stabilization program, which was built around the use of the exchange rate as a nominal anchor. The concerns were justified, in the sense that Russia is chronically susceptible to Dutch disease because of the strength of its energy sector. For a while, in 1995-97, the unfavorable debt dynamics were suppressed by the real appreciation: the debt-GDP ratio stayed constant despite the fiscal deficit because debt was mostly denominated in dollars, and dollar GDP was

1. The author acknowledges helpful comments from David Snelbecker. 
still increasing even though real GDP was falling. But in 1998 the government targeted a constant real exchange rate, which removed this clearly unsustainable prop. By May 1998 it was therefore clear to the markets that the fiscal situation was unsustainable. The stage was set for a first-generation balance of payments crisis. ${ }^{2}$

There are three interesting features of the policy response to this predicament. One is that an attempt was made to salvage the stabilization program despite the unpromising debt dynamics. The second is that the attempt failed. The third is that everyone is now convinced that the failure was a blessing in disguise. All three features merit some discussion.

Why were the Russian authorities and their Western advisers so keen to save the 1995 program? The paper suggests that there were two reasons. One is that they feared devaluation would jeopardize the one great economic policy success that Russia had finally achieved, at great cost, namely, the stabilization of inflation. The paper argues that the view was widely held, at least among the Western advisers, that inflation stabilization was a necessary and sufficient condition for the revival of growth. This was based on a paper by Stanley Fischer, Ratna Sahay, and Carlos Végh, who did indeed argue that, in the transition economies, "stabilization appears close to being both a necessary and sufficient condition for growth." ${ }^{3}$

Unfortunately, that paper really had no justification for drawing such a strong conclusion: a lot of things tended to go together when a country progressed through the transition, and there was no empirical evidence for concluding that inflation stabilization was the critical element. Indeed, the authors went on to include a liberalization index in their econometrics, and to conclude that "the state of market-oriented reforms ... appears to have been critical in spurring growth." ${ }^{4}$ The same reforms also turned out to exert a strong negative impact on inflation. This suggests that it is

2. Here I follow what is the most familiar distinction between first- and secondgeneration crisis models, according to which the former are driven by inconsistent fundamentals whereas the latter result from self-fulfilling expectations. Krugman (2000, p. 2) draws a different distinction, in which first-generation models describe crises caused by reserve depletion, whereas second-generation models are those where the costs of avoiding reserve depletion become so great as to lead a government to make an essentially political decision to devalue. (Krugman defines third-generation models as ones where crises are caused by features of the financial system such as loan guarantees and bank runs.)

3. Fischer, Sahay, and Végh (1996, p. 59).

4. Fischer, Sahay, and Végh (1996, p. 61). 
at least possible that, in the more successful transition economies, microeconomic reforms played a major role in simultaneously reducing inflation and reviving growth, rather than that the fall in inflation caused the recovery of growth. This interpretation does not suggest that repressing inflation by means of an overvalued currency and widespread barter and arrears, with market-oriented reforms left in limbo, was a likely formula for reviving growth.

The second reason given for the resistance to devaluation in Russia is that the world had recently watched devaluations produce catastrophes in East Asia, most particularly by imploding the Indonesian economy. A broader view suggests that Indonesia was actually an exception in terms of the damage done by devaluation: most other countries that devalued in the 1990s found the experience less inflationary than they had expected. Where devaluation was truly damaging was where the private sector had extensive dollar liabilities, which was most true in Indonesia and Ecuador, and to a lesser extent in Korea and Thailand. But the Russian private sector held dollar assets rather than dollar liabilities; even the banking sector does not appear to have been heavily indebted in dollars.

In any event, the Russian government and its Western advisers decided that these two reasons justified an attempt to save the stabilization program. In June and July 1998 the government and the IMF therefore went through another round of negotiations and program design. The upshot was a package with three features: a resolve to aim for a significant primary fiscal surplus in 1999, to be achieved by a series of reforms intended to harden budget constraints; $\$ 23$ billion in foreign loans; and a market-based debt swap from short-term, high-interest GKOs into long-term dollar Eurobonds so as to reduce interest costs. We all know that this package signally failed to restore confidence and was followed by complete collapse within weeks. This meant that the refinancing into dollar-denominated bonds served to increase rather than reduce the burden of debt service.

What caused the collapse? The Duma did not help by turning down some of the conditions in the package that were intended to harden budget constraints, but the paper attributes more significance to perverse effects of the new foreign loans and the debt swap. By creating senior debt, the paper argues, these actions actually undermined confidence in GKOs while providing the resources for holders of GKOs to get out, which they did. Hence the continuing reserve losses that led to moratorium, unilateral debt reconstruction, and the floating of the ruble. 
The weeks following the collapse of the Russian program marked the apogee of the most dangerous economic crisis that the world has seen in recent decades. Brazil immediately came under renewed pressure, after a Deutsche Bank conference call warned investors worldwide that they could no longer rely on being bailed out. Investors accordingly rushed for safety, which upset Long Term Capital Management's gamble that the regressions of the preceding $n$ years could be extrapolated into the future. Yet a few weeks later the crisis was all over. Brazil was shored up by a new IMF package, which lasted just long enough to get President Fernando Henrique Cardoso reelected and to allow Brazil to devalue under safer circumstances. The carry trade collapsed, restoring the yen to a sensible level that no longer threatened a new round of competitive devaluations in East Asia. The attacks that were threatening a series of emerging market currencies (whose success, incidentally, would have put paid to the naïve notion that floating currencies are crisis-proof) were called off as the hedge funds and their ilk were forced to pull back. ${ }^{5}$ The Federal Reserve and the European Central Bank lowered interest rates, and Fannie Mae injected liquidity. The world economy hardly hiccuped.

And the Russian economy revived. Although the immediate impact of floating the ruble was indeed devaluation, a spike in inflation, and a further decline in output, this did not lead to the renewed downward spiral that had been feared. On the contrary, it soon became clear that the devaluation was just what was needed to revive the import-competing sector in Russia and had finally created the circumstances in which it was possible to harden budget constraints. The authorities also got around to imposing a sensible level of taxation on energy exports, ${ }^{6}$ thus giving some hope that Russia would not relapse into Dutch disease the moment confidence began to return. One can at last dare to hope that the transition has the prospect of bringing a decent prosperity to Russia in the medium term.

5. See the report of the Market Dynamics Study Group in Financial Stability Forum (2000).

6. Let me offer one personal anecdote in this connection. One of the recommendations that I offered when in Moscow in December 1991 was something close to free trade apart from an export tax on energy, motivated by concern over the danger of Dutch disease. This failed to resonate for two reasons. One was that an energy export tax is a distortion, and at least a part of the hierarchy for which I was consulting regarded our mission in Moscow as being to eliminate distortions. The other was that such an assault on the rents of the energy czars could threaten the personal safety of the minister responsible. One has to be relieved that apparently neither of these considerations is any longer regarded as decisive. 
What morals should we draw from this story? Doubtless there are others, but let me focus on four. First, Russia was able to devalue without catastrophe because it had avoided dollarization of its liabilities. Other countries would be well advised to take the cue and minimize the holding of foreign currency liabilities by the private sector, if necessary by imposing a tax surcharge on interest payments on foreign currency debt.

Second, the absence of overvaluation cannot be inferred simply from the absence of a current account deficit. Import demand in Russia was low because the economy had a lot of excess capacity in the importcompeting sector. Exports were high because the economy had a strong energy sector. The precrisis macroeconomic equilibrium was a highly undesirable one. Neither Russian officials nor their foreign advisers get high marks for having failed to appreciate that.

Third, price stability achieved at the cost of overvaluation should not be considered successful stabilization. It is a way of repressing inflation temporarily, by passing to the foreign sector the costs of resolving the distributive inconsistencies that underlie most inflationary episodes. It should accordingly be expected to blow up, and it is a mistake to give foreign support to programs based on such insecure foundations. The idea that devaluations are always to be avoided, irrespective of the degree of overvaluation, is the sort of nonsense one expects to read on the Wall Street Journal editorial page rather than to find being taken as the basis for serious policymaking. ${ }^{7}$

Fourth, by creating a lot of senior debt, throwing money at a country with doubtful solvency may increase the incentive as well as the potential for foreign investors to exit. Bailouts should be confined to cases where the balance of the evidence suggests that the problem is one of illiquidity and not insolvency.

Let me address in closing the issue of whether the paper and this discussion provide reasons for censuring the Western policymakers who tried to save the Russian program in the summer of 1998. With the benefit of hindsight, I think it is clear enough that it would have been better to persuade the Russians to devalue in May. Indeed, I like to think that, on the

7. Unfortunately, exchange rate policy in some quarters in Washington at the time consisted in endlessly averring love for a strong dollar, a formulation that may conceivably have desensitized those who made such proclamations from recognizing that exchange rates can be too strong as well as too weak. 
evidence then available of the ruble's overvaluation, I would have argued in favor of a program that included devaluation in one way or another had I been involved in that discussion. But such a course of action would have had its own risks. ${ }^{8}$ And if I had been in Stanley Fischer's shoes, I, too, would have blanched at forcing the Russians to devalue, or to float, if they could not be persuaded by reason to do so. Hence I hesitate to assign blame about the past, and in any event what is more important is to learn lessons regarding the future.

General discussion: Stanley Fischer remarked that Lawrence Summers' comments on the paper provided an accurate description of official thinking at the time of the crisis, and of subsequent reflections on the crisis and rescue program. He went on to offer a number of supplementary remarks.

The IMF had made financing conditional on decisions by the Duma to raise revenue because the alternative, decisions imposed by decree, had proved ineffective. Fund management also believed that if the Russian government could not obtain the Duma's support at this time of major economic crisis, it would be unable to carry out the rest of the program-in which case financial support for Russia would not be justified.

Fischer agreed with the authors' suggestion that it was critical in mid1998 to restore confidence, but he did not believe that merely providing more money would have achieved that goal. The restoration of confidence needed both money and a change in the policies that had produced the crisis. Accordingly, the program linked the provision of financing to the implementation of fiscal and structural measures, in the belief that investors would be persuaded to continue holding Russian assets by the combination of the provision of liquidity in the short run and the assurance that policy changes were under way to reduce the fiscal deficit and ensure the stability of debt dynamics.

Fischer argued that it was and is far less clear that the ruble was overvalued before the crisis than the paper implied. Russia had massive current account surpluses until the oil price collapsed. It has massive surpluses again today, and only capital flight—which should not be welcomed in a

8. Some of these are emphasized by Stanley Fischer in the general discussion of the paper. 
country with such enormous financial needs-keeps the overall balance of payments surplus at a reasonable level. One of the goals of the Russian package in July 1998 was to reverse the persistent capital flight that was then taking place. In attempting to gauge the real exchange rate, the IMF looked at real wages and other indicators, which had not provided clear evidence of overvaluation. There was no strong case for a large devaluation, unless one relies entirely on the argument that devaluation is always helpful—and the more the better.

Fischer turned to the strategy of pegging the exchange rate. He noted that there have been few instances of reducing very high inflation rates without pegging the exchange rate, but he observed that finding an exit from that strategy was both key and difficult. Given how infrequently triple-digit inflations have been stabilized without an exchange rate peg, he observed that it was a difficult judgment in these circumstances whether to keep trying to stabilize from high inflation with a floating rate- and failing repeatedly — or to attempt to disinflate by using an exchange rate peg, with the intention of exiting in time but recognizing that this involves a higher risk of crisis. Along the same lines, he raised the theoretical possibility that the social costs of a stabilization achieved with a peg and a crisis, but that ends with a low rate of inflation, might be less than the costs of an alternative path that avoids crisis but does not reduce inflation.

Regarding the restructuring of debt, Fischer was skeptical that a marketfriendly restructuring alone can fundamentally change a country's debt dynamics. Such restructurings take place at market prices, and thus almost by definition do not significantly change the present value of the country's debt obligations, unless they in effect reduce the value of existing claims by creating new claims that are more senior. He reported that the Russians had discussed whether it would be possible to restructure the debt without devaluing, or to devalue without restructuring the debt, but had concluded that doing one would immediately force the other.

Finally, Fischer noted several qualifications to John Williamson's statement that the changes resulting from the crisis showed it to be "a blessing in disguise." This ignored the contagion effects of the crisis, which hit many countries-including for a short while the United States-and contributed to Brazil's 1999 devaluation and Argentina's present difficulties. Further, Russia was fortunate to avoid pitfalls that were widely feared in August 1998 and that could have produced much worse outcomes. The 
Kirienko government fell, and the Primakov government initially declared its intent to undo many of the reforms of the previous seven years, and to accept rapid inflation.

As it turned out, the Russian public wanted neither higher inflation nor to roll back the reforms-lower inflation had surely been one of the most important achievements of Russian economic reform during the previous years. With the help of higher oil prices, the economy started a recovery in 1999. But these fortunate outcomes could not have been counted on when the decision to help Russia try to maintain the peg was made in the summer of 1998.

Ronald McKinnon saw the genesis of the Russian problem in the big bang of 1992, when capital controls were eliminated and the government's ability to impose prudential regulation on the banking system was greatly limited. Under these circumstances, when ruble interest rates became very high, it was almost impossible to keep banks and other institutions from borrowing in dollars, without hedging their foreign currency exposure, to lend at the high ruble rates. He contrasted the Russian situation with that in China, where capital controls have been used to prevent Chinese banks and corporations from taking on undue exchange rate risk. $\mathrm{He}$ also suggested that the depth of a country's financial system, rather than the size of its GDP, indicated its ability to sustain fiscal deficits, since the former reflects the capacity of the banking system to finance deficits. China has no immediate problem financing its fiscal deficits, which are much larger relative to GDP than Russia's, because the huge stock of domestic bank deposits (broad money) permits the Chinese government to borrow heavily from its banks without causing inflation.

Martin Baily emphasized that geopolitical considerations justified attempting a rescue package for Russia even if the chances of success were not high. That market participants understood this helps explain the willingness of many to remain exposed on the eve of the crisis. Baily also remarked that the weakness in the Russian economy, including the need to subsidize industries to maintain employment and the government's inability to collect revenue, should have been evident to any investors who took the trouble to look. This reinforced the idea that investors were relying on a "too big to fail" argument. He reasoned that the large losses many investors suffered would reduce their reliance on such reasoning in the future. Baily disagreed with Fischer about the exchange rate, observing that all reports he had received in the months just before the crisis indi- 
cated that the tradable goods sector was uncompetitive. He reasoned that such an uncompetitive rate could not have been sustained for any extended period.

Richard Cooper felt that the role of oil prices in the crisis should have received more attention in the paper. The price of oil, Russia's major export, dropped below $\$ 10$ a barrel in early 1998. The paper dismissed the importance of this decline because revenue was not tied to oil prices at that time. However, Cooper reasoned, market participants either may have been unaware of this or might well have counted on higher oil receipts as a revenue source in the future. Either way, market confidence in the ruble would have been greater, and projections of the Russian fiscal situation more favorable, had the oil price not crashed. In the same vein, he suspected that rising oil prices helped stabilize the Russian situation in the two years following the crisis.

William Branson recalled a study conducted in the summer of 1998 that provided a direct indication of sovereign risk from forward markets, supporting the paper's analysis of default risk. Using daily data, the study showed large deviations from covered interest parity in the ruble-dollar forward market, with the deviations growing with the maturity of contracts.

Shang-Jin Wei argued that corruption played an important role in the crisis and in the dynamic of capital flight because it biased the composition of foreign investment. Most foreign investment went into GKOs and was easily reversed. Very little took the form of foreign direct investment or investment in equities. He concluded that Russia would have been less vulnerable if eliminating corruption had been a larger part of the reform effort. 


\section{References}

Ahrend, Rudiger. 1999. "Russia's Post-Stabilization Decline, Crash and Revival: Don't Blame the Corruption-It's the Exchange Rate, Stupid." Russian Economic Trends 3: 20-24.

Åslund, Anders. 1995. How Russia Became a Market Economy. Brookings Institution Press.

Black, Bernard, Reinier Kraakman, and Anna Tarassova. 2000. "Russian Privatization and Corporate Governance: What Went Wrong?" Stanford Law Review 52: 1731-1808.

Blasi, Joseph R., Maya Kroumova, and Douglas Kruse. 1997. Kremlin Capitalism: The Privatization of the Russian Economy. Cornell University Press.

Buckberg, Elaine, and Brian Pinto. 1997. "How Russia Is Becoming a Market Economy. A Policy Maker's Checklist.” Unpublished paper. Washington: International Finance Corporation (September).

Burnside, Craig, Martin Eichenbaum, and Sergio Rebelo. 1999. "Prospective Deficits and the Asian Currency Crisis." Working Paper 2174. Washington: World Bank.

Calvo, Guillermo A. 1996. "Why Is 'the Market' So Unforgiving? Reflections on the Tequilazo." Unpublished paper. University of Maryland (September).

Calvo, Guillermo A., and Carmen M. Reinhart. 1999. "When Capital Inflows Come to a Sudden Stop: Consequences and Policy Options." Unpublished paper. University of Maryland (June).

Commander, Simon, and Christian Mumssen. 1998. "Understanding Barter in Russia." Working Paper 37. London: European Bank for Reconstruction and Development.

Dooley, Michael P. 1998. “A Model of Crises in Emerging Markets.” International Finance Discussion Paper 630. Washington: Board of Governors of the Federal Reserve System (November).

Dornbusch, Rudiger, Ilan Goldfajn, and Rodrigo D. Valdés. 1995. "Currency Crises and Collapses." BPEA, 2:1995, 219-70.

Dornbusch, Rudiger, and Alejandro Werner. 1994. "Mexico: Stabilization, Reform, and No Growth." BPEA, 1:1994, 253-97.

Eichengreen, Barry, Andrew K. Rose, and Charles Wyplosz. 1996. "Contagious Currency Crises.” Scandinavian Journal of Economics 98(4): 463-84.

Eichengreen, Barry, and Christof Ruehl. 2000. "The Bail-in Problem: Systematic Goals, Ad Hoc Means.” Working Paper 7653. Cambridge, Mass.: National Bureau of Economic Research (April).

Financial Stability Forum. 2000. Report of the Working Group on Highly Leveraged Institutions. Basel.

Fischer, Stanley, Ratna Sahay, and Carlos A. Végh. 1996. "Stabilization and Growth in Transition Economies: The Early Experience." Journal of Economic Perspectives 10(2): 45-66. 
Flood, Robert P., and Peter M. Garber. 1984. "Collapsing Exchange-Rate Regimes: Some Linear Examples." Journal of International Economics 17(1-2): 1-13.

Flood, Robert P., and Olivier Jeanne. 2000. "An Interest Rate Defense of a Fixed Exchange Rate?” IMF Working Paper WP/00/159. Washington: International Monetary Fund (October).

Frankel, Jeffrey A., and Alan T. MacArthur. 1988. "Political vs. Currency Premia in International Real Interest Differentials: A Study of Forward Rates for 24 Countries." European Economic Review 32(5): 1083-1114.

Furman, Jason, and Joseph E. Stiglitz. 1998. "Economic Crises: Evidence and Insights from East Asia." BPEA, 2:1998, 1-114.

General Accounting Office. 2000. Foreign Assistance: International Efforts to Aid Russia's Transition Have Had Mixed Results. Report GAO-01-8. Washington.

International Monetary Fund. 2000a. Russian Federation: Staff Report for the 2000 Article IV Consultation and Public Information Notice Following Consultation. Staff Country Report 00/145. Washington.

—. 2000b. "Debt- and Reserve-Related Indicators of External Vulnerability." Washington (www.imf.org/external/np/pdr/debtres/debtres.pdf [March 23]).

Kharas, Homi, and Deepak Mishra. 2001. "Fiscal Policy, Hidden Deficits and Currency Crisis." In World Bank Economists' Forum, edited by Shantayanan Devarajan, F. Halsey Rogers, and Lyn Squire. Washington: World Bank.

Krugman, Paul R. 1979. "A Model of Balance-of-Payments Crises." Journal of Money, Credit and Banking 11(3): 311-25.

_ 2000. "Introduction." In Currency Crises, edited by Paul R. Krugman. University of Chicago for the National Bureau of Economic Research.

Lieberman, Ira W., and Rogi Veimetra. 1996. "Rush for State Shares in the 'Klondyke' of Wild East Capitalism: Loans-for-Shares Transactions in Russia." George Washington Journal of International Law and Economics 29(3): 737-68.

Loungani, Prakash, and Paolo Mauro. 2000. "Capital Flight from Russia." IMF Policy Discussion Paper 00/06. Washington: International Monetary Fund (April).

Organization for Economic Cooperation and Development. 1997. OECD Economic Surveys: Russian Federation. Paris.

Pinto, Brian, Vladimir Drebentsov, and Alexander Morozov. 2000a. "Dismantling Russia's Nonpayments System: Creating Conditions for Growth." World Bank Technical Paper 471. Washington: World Bank.

2000b. "Give Macroeconomic Stability and Growth in Russia a Chance: Harden Budgets by Eliminating Non-payments." Economics of Transition 8(2): 297-324. 
Sargent, Thomas J., and Neil Wallace. 1981. "Some Unpleasant Monetaristic Arithmetic." Federal Reserve Bank of Minneapolis Quarterly Review 5(3): $1-17$.

Slay, Ben. 1999. “An Interpretation of the Russian Financial Crisis.” Post-Soviet Geography and Economics 40(3): 206-14.

Tompson, William. 1997. "Old Habits Die Hard: Fiscal Imperatives, State Regulation and the Role of Russia's Banks.” Europe-Asia Studies 49(7): 1159-85. 